\title{
Popularising and Personalising an Illustrated Herbal in Dutch
}

\author{
Andrea van Leerdam | ORCID: 0000-0003-0391-8370 \\ Utrecht University, Utrecht, The Netherlands \\ A.E.vanLeerdam@uu.nl
}

\begin{abstract}
Who were illustrated herbals intended for, who were the actual readers and how did they use these books? The case of the Dutch herbal Den groten herbarius met al sijn figueren ("The great herbal with all its figures") sheds light on book producers' strategies of popularisation and readers' strategies of personalisation. Between 1514 and 1547, at least six illustrated folio editions appeared, with connections to German and English herbal traditions. The work's paratexts point to a wide intended audience and to a key role for the illustrations in popularisation strategies. Early modern users' traces in a corpus of 27 individual copies reveal owners from a variety of backgrounds who seem to share a predominantly practical interest in remedies. The article focuses on three pervasive practices of personalisation that offer new perspectives on readers' engagement with materia medica: tagging recipes and plant names, attaching pins to the pages, and colouring woodcuts.
\end{abstract}

\section{Keywords}

herbals - woodcuts - reading practices

\section{Introduction}

There is something paradoxical about the body of surviving medical works printed in Dutch in the first half of the sixteenth century. The illustrated herbal Den groten herbarius met al sijn figueren ("The great herbal with all its figures," from here on: Den groten herbarius) survives in a relatively large number of editions and individual copies, while these copies also generally show more 
signs of use than other Dutch medical works from this period such as health regimens or surgical treatises. ${ }^{1}$ Many of the surviving copies were apparently heavily used, though not read to destruction. Who were illustrated herbals intended for, who were the actual readers and how did they use these books? In this article I use the case of the Dutch Den groten herbarius to contribute to our understanding of these matters. The relevance of this case lies not just in the amount of surviving material, but also in the often overlooked position of Den groten herbarius as a node in the international network of early printed herbals.

Printed herbals were a widespread type of books across Europe in the late fifteenth and early sixteenth century, both in Latin and vernaculars. Building on manuscript traditions that went back to Antiquity, printed herbals describe the names and properties of plants and other natural substances, with a special focus on their medicinal qualities and recipes to apply them against all kinds of ailments. ${ }^{2}$ Recent studies have problematised the deceptively simple question of how early printed herbals were used in practice. ${ }^{3}$ Much scholarly attention has been-and continues to be-devoted to the place of herbals in the history of science, notably in the development of early modern botany and the

1 This is one of the findings from my PhD research, to be completed in 2021 at Utrecht University, based on a corpus of fifteen illustrated medical and astrological works published in Dutch (1500-1550) in ca. 5 o editions and ca. 120 individual copies. The research for this article was made possible through a PhD grant from the Netherlands Organisation for Scientific Research (NWO) and short-term fellowships from the Renaissance Society of America and the Bibliographical Society of America. I thank Sabrina Minuzzi, Anna-Luna Post, Cora van de Poppe, Jaap de Haan, Stan van Zon, Maja van Leeuwen, Bart Besamusca, Arnoud Visser, and the anonymous peer reviewers of Nuncius for their thoughtful comments on earlier versions of this paper.

2 On the ancient and medieval manuscript herbal tradition, see Minta Collins, Medieval Herbals: The Illustrative Traditions (London: British Library, 2000); Wilfrid Blunt and Sandra Raphael, The Illustrated Herbal (London: Frances Lincoln, 1979), 10-119; Frank J. Anderson, An Illustrated History of the Herbals (New York: Columbia University Press, 1977), 30-120.

3 Dominic Olariu, “The Misfortune of Philippus de Lignamine's Herbal, or New Research Perspectives in Herbal Illustrations from an Iconological Point of View," in Early Modern Print Culture in Central Europe. Proceedings of the Young Scholars Section of the Wroctaw Seminars, September 2013, ed. Stefan Kiedroń, Anna-Maria Rimm, and Patrycja Poniatowska (Wrocław: Wydawnictwo Uniwersytetu Wrocławskiego, 2014), 39-62; Leah Knight, Of Books and Botany in Early Modern England: Sixteenth-Century Plants and Print Culture (Farnham: Ashgate, 20o9); Elaine Leong, "'Herbals she peruseth': Reading Medicine in Early Modern England," Renaissance Studies 28, no. 4 (2014): 556-578; Jean A. Givens, "Reading and Writing the Illustrated Tractatus de herbis," in Visualizing Medieval Medicine and Natural History, 1200-1550, ed. Jean A. Givens, Karen M. Reeds, and Alain Touwaide (Aldershot: Taylor and Francis, 2006), 115-145; Claudia Swan, "Realism in Early Modern Illustrated Botany," in Givens, Reeds, and Touwaide, Visualizing Medieval Medicine, 239-249. 
emergence of a more empirical approach to the pursuit of knowledge. ${ }^{4} \mathrm{How}-$ ever, the assumption that images in printed herbals were primarily intended for the identification of plants has been challenged in recent years by various scholars who discuss the intermingling of naturalistic and schematic features in the images and the heavy influence of iconographic traditions and practices of copying and reusing woodcuts. ${ }^{5}$ In light of the numerous herbals without images, Claudia Swan has raised the question why herbals would be illustrated at all. ${ }^{6}$

Besides the context of botany, at least equally important for our understanding of the functions of illustrated herbals is an awareness that not all readers of herbals were botanists or naturalists, or indeed medical experts. The early modern medical practice in which knowledge of plants was applied, was highly variegated: medical care was not only provided by university-trained physicians and professionally trained surgeons, barbers and apothecaries, but also by all kinds of autodidact and parttime practitioners, in households, local communities, and convents, for example. ${ }^{7}$ With respect to practical use, not only the images but also the texts of printed herbals raise questions. Historians of knowledge have pointed out that early modern recipes call on vast bodies of tacit knowledge, for example on diagnosis and on required quantities, tools, and methods of preparation. ${ }^{8}$ Even though much remains to be discovered

4 Sachiko Kusukawa, Picturing the Book of Nature: Image, Text, and Argument in SixteenthCentury Human Anatomy and Medical Botany (Chicago: University of Chicago Press, 2012); Brian W. Ogilvie, The Science of Describing: Natural History in Renaissance Europe (Chicago: University of Chicago Press, 2006); Anderson, Illustrated History; Agnes Arber, Herbals: Their Origin and Evolution: A Chapter in the History of Botany, 1470-1670 (Cambridge: University Press, 1912).

5 Bruce T. Moran, "Preserving the Cutting Edge: Traveling Woodblocks, Material Networks, and Visualizing Plants in Early Modern Europe," in The Structures of Practical Knowledge, ed. Matteo Valleriani (Cham: Springer, 2017), 393-419; Olariu, "The Misfortune," 42-49; David Landau and Peter Parshall, The Renaissance Print, 1470-1550 (New Haven: Yale University Press, 1994), $245^{-259}$.

6 Swan, "Realism."

7 Peter Murray Jones, "Medical Literacies and Medical Culture in Early Modern England," in Medical Writing in Early Modern English, ed. Irma Taavitsainen and Päivi Pahta (Cambridge: University Press, 2011), 30-43; John Henry, "Doctors and Healers. Popular Culture and the Medical Profession," in Science, Culture and Popular Belief in Renaissance Europe, ed. Stephen Pumfrey, Paolo L. Rossi, and Maurice Slawinski (Manchester: University Press, 1991), 191221; Margaret Pelling and Charles Webster, "Medical Practitioners," in Health, Medicine and Mortality in the Sixteenth Century, ed. Charles Webster (Cambridge: University Press, 1979), 165-235.

8 Mary Fissell, "Popular Medical Writing," in The Oxford History of Popular Print Culture, vol. 1: Cheap Print in Britain and Ireland to 1660, ed. Joad Raymond (Oxford: University Press, 2011), 


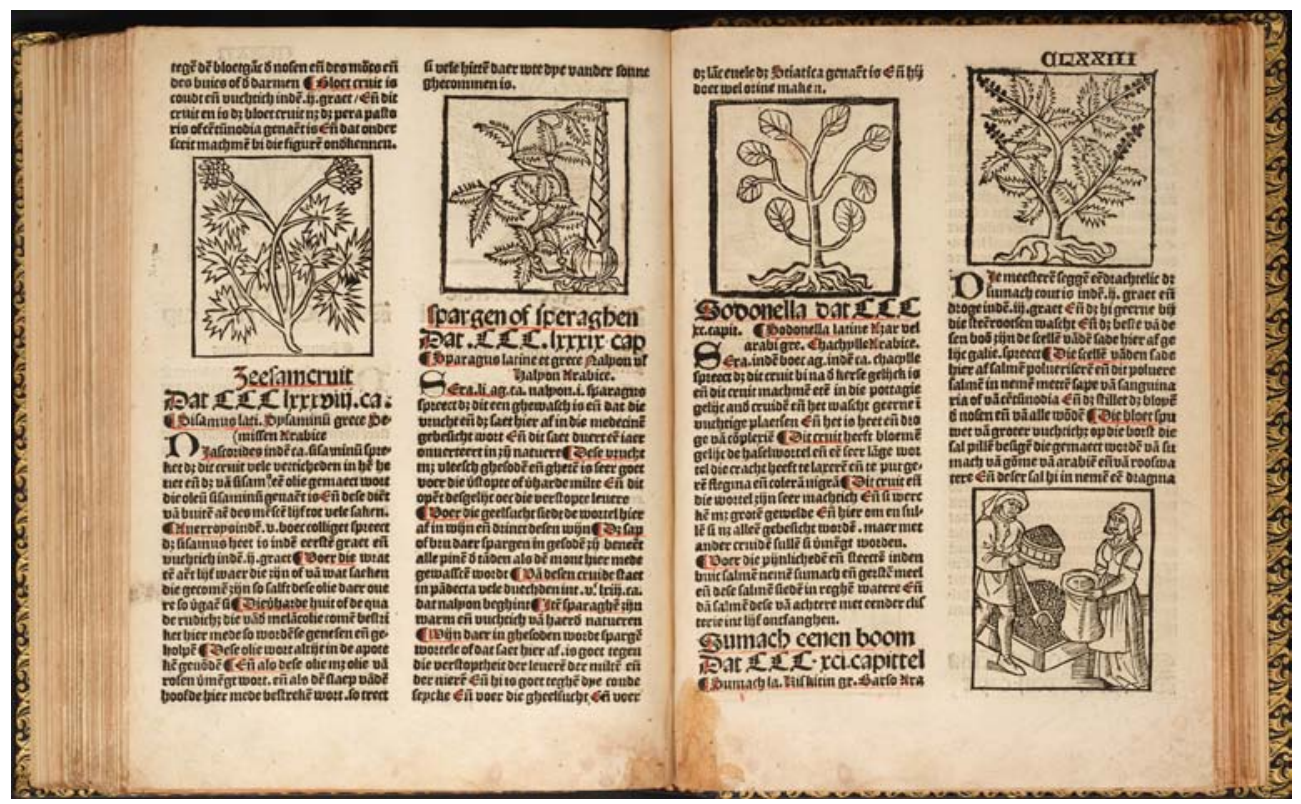

FIGURE 1 Den groten herbarius (Antwerp, Claes de Grave 1514)

AMSTERDAM, ALLARD PIERSON, UNIVERSity OF AMSTERDAM, NED. INC. 509, FOLS. $\mathrm{E} 5^{\mathrm{V}}-\mathrm{E} 6^{\mathrm{R}}$

about who possessed such knowledge and how they acquired it, the lack of explicit instructions in herbals apparently has not hampered their extensive use by numerous readers, as the case of Den groten herbarius testifies.

The first edition of this voluminous and extensively illustrated herbal appeared in 1514, published by Claes de Grave (Nicolaes Grapheus) in Antwerp (Fig. 1). He set the standard for the subsequent editions in Dutch, of which there were at least five until 1547 (see Appendix 1). ${ }^{9}$ All six editions are in folio, and

421; Sara Pennell, "Perfecting Practice? Women, Manuscript Recipes and Knowledge in Early Modern England," in Early Modern Women's Manuscript Writing: Selected Papers from the Trinity/Trent Colloquium, ed. Victoria E. Burke and Jonathan Gibson (London/New York: Routledge, 2004), 238-239.

9 Secondary literature on Den groten herbarius is scant. The work is briefly discussed in Andrea van Leerdam and Jessie Wei-Hsuan Chen, "Healthy Herbs in Print" (Utrecht, University Library, 2017), https://www.uu.nl/en/utrecht-university-library-special-collections/collection s/early-printed-books/popular-printed-material/den-groten-herbarius, accessed April 12, 2021; W. De Backer et al., Botany in the Low Countries (end of the 15th century-ca. 1650) (Antwerp: Plantin-Moretus Museum, 1993), 89-9o; Piet J.A. Franssen, Tussen tekst en publiek. Jan van Doesborch, drukker-uitgever en literator te Antwerpen en Utrecht in de eerste helft van de zestiende eeuw (Amsterdam: Rodopi, 199o), 72, 87-88, 199; Hendrik D.L. Vervliet, Post- 
all of them contain 435 short, numbered chapters on plants and other natural resources that have medicinal qualities. Each chapter is preceded by a woodcut illustration and then gives a brief characterisation of a plant's qualities, its appearance, the workings of its various parts, and medicinal recipes for its application. Short additional treatises at the end of the book, increasing in number in each new edition, deal with such topics as uroscopy, anatomy, the preparation of ointments and plasters and other medicines, and cultivating trees.

Den groten herbarius contains several indications that its producers combined and adapted different sources in order to appeal to an audience that extended well beyond medical practitioners, and that the illustrations played a key role in this presentational strategy. The first part of this article discusses the producers' choices and shows how these were influenced by and subsequently followed in other herbals, thus situating Den groten herbarius within the international bibliographical maze of printed herbals. The second part of the article analyses whether printers succeeded in reaching a broad audience, by studying a corpus of 27 individual copies of the six known editions for marks of ownership and traces of use. ${ }^{10}$ This study reveals owners from a variety of backgrounds and a variety of ways in which early modern readers personalised their books to suit their own purposes. I will focus on three recurrent practices that shed new light on readers' engagement with printed herbals: tagging remedies and plant names, attaching pins to the pages, and colouring woodcuts.

\section{$2 \quad$ Intended Readers: Popularising Medical Knowledge}

Den groten herbarius draws on three different traditions, for its text, its images, and its title. The text is a translation of the German Gart der Gesundheit (the Garden of Health, also called the "smaller Ortus"), first printed in Mainz by

incunabula en hun uitgevers in de Lage Landen/Post-Incunabula and Their Publishers in the Low Countries (The Hague/Boston/London: Nijhoff, 1978), 200-201; Claus Nissen, Die botanische Buchillustration. Ihre Geschichte und Bibliographie, and ed. (Stuttgart: Anton Hiersemann, 1966), nrs. 2289-2294.

10 To my knowledge, a total of 35 copies is held in public collections (see Appendix 2). This number is based on the Universal Short Title Catalogue and my own corrections and additions based on library catalogue searches and secondary literature. Whilst 35 is a substantial number compared to other Dutch medical works from the first half of the sixteenth century, it is obviously a tiny part of the original print runs. On issues of survival, see Flavia Bruni and Andrew Pettegree, eds., Lost Books: Reconstructing the Print World of PreIndustrial Europe (Leiden: Brill, 2016). 
Peter Schöffer in $1485 .{ }^{11}$ The woodcuts in Den groten herbarius derive from another famous herbal first printed in Mainz: the Latin Hortus sanitatis (Jacob von Meydenbach, 1491). ${ }^{12}$ The combination of text from the Gart der Gesundheit and images from the Hortus sanitatis had already appeared in In disem buch ist der herbary: oder krüterbuch: genant der gart der gesuntheit, published by Johann Prüss in Strasbourg in 1507 (henceforth: Herbary). ${ }^{13}$ This edition, or perhaps a now-lost one that was very closely related, must have been the direct source for Den groten herbarius (Fig. 2 and $3 \mathrm{~B}$ ). The title, however, bears most resemblance to the French Le grant herbier, of which the earliest known editions date from the 149os. ${ }^{14}$ This section will discuss what the combination of these different traditions reveals about the book's intended users and intended use.

\section{1}

\section{"The learned and the unlearned"}

In the early print era, printers faced the new challenge of estimating the market size and of attracting buyers for each edition. That this could be challenging even for a widely printed genre as herbals, is suggested by Claes de Grave's 1533 edition of Den groten herbarius. It was published just a year after Jan van Doesborch's (1532), perhaps as a response because Van Doesborch had added a treatise on preparing medicines that was not in De Grave's earlier editions of 1514 and $15^{26}$. In the 1533 edition, De Grave included this treatise, too, and added another one on syphilis or "Spanish pox," as well as a new title page woodcut that clearly resembled Van Doesborch's. The core of the 1533 edition, however, consisted of leftover copies from the 1526 print run. ${ }^{15}$ De Grave's 1526 edition,

11 Johannes de Cuba, Gart der Gesundheit (Mainz: Peter Schöffer, 28 March 1485), 2 ${ }^{\circ}$ ISTC igooo970oo, GW Mo9766.

12 Hortus sanitatis (Mainz:Jakob Meydenbach, 23June 1491), $2^{\circ}$, ISTC ihoo486ooo, GW 13548.

13 As noted by Mechtild Habermann, Deutsche Fachtexte der frühen Neuzeit. Naturkundlichmedizinische Wissensvermittlung im Spannungsfeld von Latein und Volkssprache (Berlin/ New York: Walter de Gruyter, 2001), 246. In disem buch ist der herbary: oder krüterbuch: genant der gart der gesuntheit (Strasbourg: Johann Prüss, 1507), 2 ${ }^{\circ}$, VD 16 W $435^{8}$ (http:// gateway-bayern.de/VD16+W+4358). Habermann does not link the Herbary to Den groten herbarius.

14 The French text is largely based on the Circa instans attributed to Platearius. The oldest known edition dates from c. 1486-1488 and is titled Arbolayre (Besançon: Pierre Metlinger), $2^{\circ}$, ISTC iaoo94400O, GW02312. The subsequent editions bear the title Le grant herbier. Anderson, An Illustrated History, chap. 13.

15 Apart from the title page and the added treatises at the end, all pages in the 1533 edition are identical to that of $15^{26}$, as becomes clear from a close comparison of the typesetting. All particulars, like the positioning of quire signatures, woodcut initials with wormholes (e.g., fol. $\mathrm{p} 4^{\mathrm{r}}$ ), and the woodcut of wijnsteen (cream of tartar) erroneously printed upside down $\left(\right.$ fol. $\left.\mathrm{F}_{2}{ }^{\mathrm{v}}\right)$, are the same. 

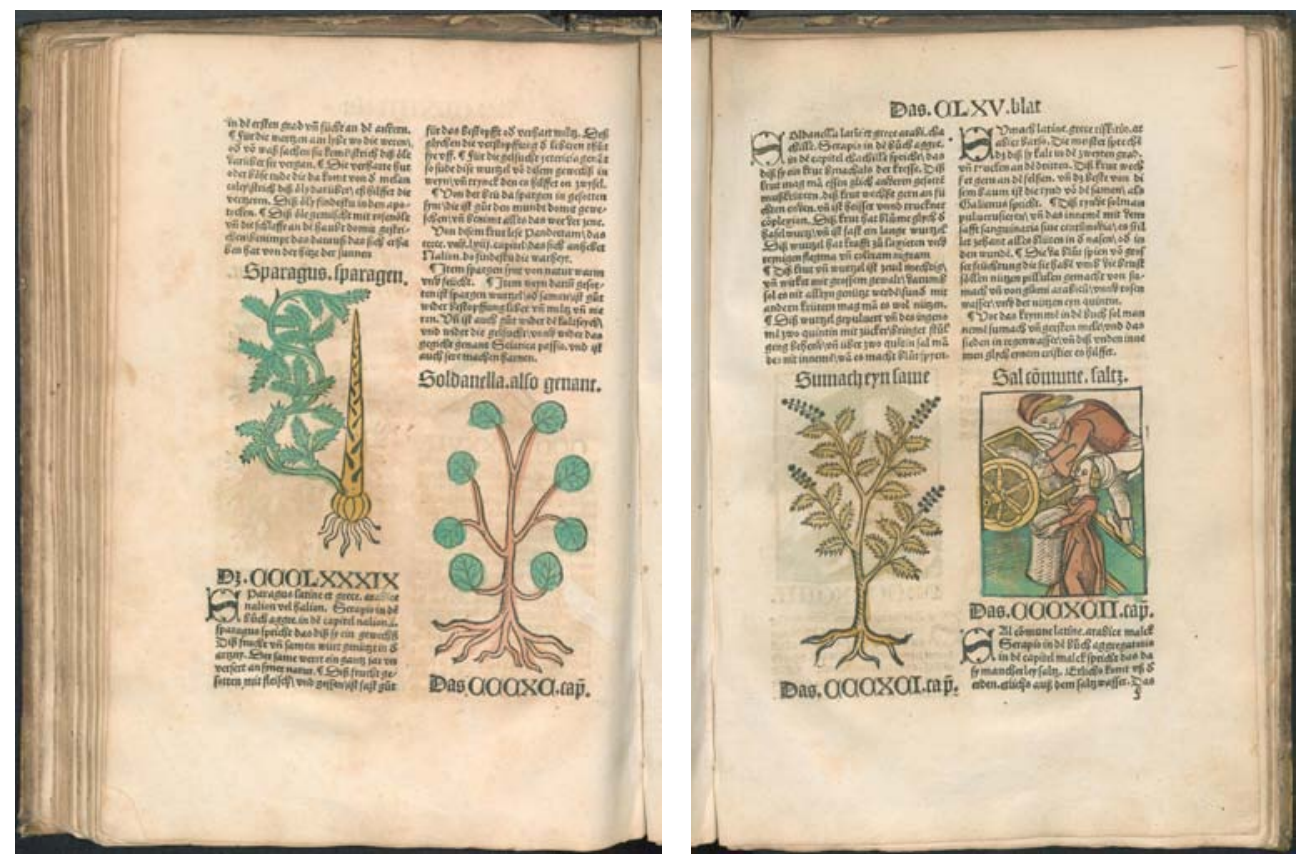

FIGURE 2 In disem buch ist der herbary: oder krüterbuch: genant der gart der gesuntheit (Strasbourg, Johann Prüss 1507)

LONDON, WELLCOME LIBRARY, EPB/D/3322, FOL. E6 $6^{\mathrm{V}}$ AND FOL. F1 ${ }^{\mathrm{R}}$

then, had not yet sold out by 1533. This case underlines that competition could be fierce. To appeal to prospective buyers, printers had every interest in making clear for whom their products were meant.

Various paratextual features show that the publishers of Den groten herbarius were targeting a wide audience. Like the German Gart der Gesundheit, the Dutch prologue emphasises that the work is intended for the ghemeen profijt, or common benefit, and both for the "learned" and the "unlearned," the latter meaning those who do not read Latin. ${ }^{16}$ The editions from 1532 onwards claim to include "a proven treatise for people who live in villages and castles far away from the masters." These editions thus present themselves as do-ityourself handbooks of medical knowledge. ${ }^{17}$ Such appeals to non-specialist

16 Ed. 1514, fol. $\mathrm{a1}^{\mathrm{v}}, \mathrm{a}^{\mathrm{r}}$ (den gheleerden ende den ongeleerden te profijte).

17 The reference to people in villages and castles far away from the masters also appears in the prologue to The grete herball (London: Peter Treveris, 1526 , fol. $+2^{\mathrm{r}}$ ) and in Hieronymus Brunschwig's Large Book of Distillation (Strasbourg: Johann Grüninger, 1512, fol. $283^{\mathrm{r}} / \mathrm{ar}^{\mathrm{r}}$ ); Franssen, Tussen tekst en publiek, 211. 
audiences should not be dismissed as mere rhetorical commonplaces. In medical books they can be seen as reflections of the multifaceted healthcare market and of a generally growing interest in how-to books. ${ }^{18}$

Whatever readers' medical experience, it is clear that Den groten herbarius was meant for practical use, as a resource of remedies. Its alphabetically arranged short chapters and the inclusion of finding aids such as indexes and chapter titles facilitate selective reading. ${ }^{19}$ The index of remedies from head to feet is preceded by an extensive appraisal of its usefulness and an explanation of how to use it. The text passage, literally translated from the German Gart der Gesundheit, suggests that both the German and the Netherlandish book producers aimed to cater for readers who were less experienced in using such a tool. ${ }^{20}$

The choice to include images deriving not from the Gart der Gesundheit but from the Hortus sanitatis was probably also part of the strategy to appeal to a wide audience. In contrast to the Gart der Gesundheit, the Hortus sanitatis contains not just images of plants, but also lively narrative images of people engaged in processing or extracting natural resources, and of animals (Fig. 3a-f). ${ }^{21}$ Claes de Grave, then, chose to copy a set of illustrations for Den groten herbarius with not just epistemic value but also entertainment value. Apparently, he preferred the arrangement of texts and images from the German Herbary over copying another illustrated Dutch herbal, Den herbarius in dijetsche, which had been published only three years before Den groten herbarius, in 1511, and which contained only plant images and no narrative images. ${ }^{22}$

18 On the codification of how-to knowledge, see Valleriani, Structures of Practical Knowledge, and Pamela Smith, "Why Write a Book? From Lived Experience to the Written Word in Early Modern Europe," Bulletin of the German Historical Institut 47 (2010): 25-5o.

19 Mary Fissell considers an "item-by-item format" and finding aids as key characteristics of popular medical works intended for practical use; Fissell, "Popular Medical Writing," 422.

20 The perceived need to explain tools for selective reading had existed for centuries; it evinces the long histories of reading technologies we now take for granted. Richard H. Rouse and Mary A. Rouse, "Statim invenire: Schools, Preachers, and New Attitudes to the Page," in Renaissance and Renewal in the Twelfth Century, ed. Robert L. Benson et al. (Cambridge, MA: Harvard University Press, 1982), 201-225.

21 The gigantic Hortus sanitatis contains books on plants as well as land animals, birds, fish, stones, with a total of over a thousand woodcuts. Roughly half of these depict plants. In Den groten herbarius, like in the German Herbary of 1507, not only plants but also a dozen or two of the woodcuts depicting stones and other resources have been copied. Whereas the plant images are all used just once, these narrative woodcuts, showing people in action with the natural resources, are repeated several times within the book.

Den herbarius in dijetsche (Antwerp: Govaert Bac, 1511), 4ㅇ, NK 1049. 
It was an influential choice in any case: De Grave's illustration programme was largely followed in all subsequent Dutch editions of Den groten herbarius.

The influence of De Grave's choice of illustrations extends even further, to the English herbal tradition: close copies of his woodblocks were used in The grete herball of ${ }_{152} 6$ (Fig. ${ }_{3} \mathrm{C}-3 \mathrm{D}$ ). ${ }^{23}$ This Dutch influence is not always recognised in studies of the English herbal. ${ }^{24}$ The copied blocks were subsequently reused in The vertuose boke of Distyllacyon (1527) and in the 1529 edition of The grete herball. ${ }^{25}$ The blocks then must have travelled back to the Low Countries, as they reappear in Jan van Doesborch's 1532 edition of Den groten herbarius (Fig. 3 E). ${ }^{26}$ Jan Berntsz, who worked together with Van Doesborch in the 153 os and took over much of his material after Van Doesborch's death in 1536, used the same woodblocks in his 1538 edition. ${ }^{27}$ In the 1547 edition, finally, Symon Cock reused part of the woodblocks from De Grave that he had apparently come to possess (Fig. $3 \mathrm{~F}$ ), and he had the other blocks made as close copies after De Grave's editions. ${ }^{28}$

23 The grete herball (London: Peter Treveris, 1526), $2^{\circ}$, ESTC sio6og6. The text of The grete herball is a translation of the French Le grant herbier. The illustrations in Le grant herbier also derived from the Hortus sanitatis, but they did not include the narrative images of people in action. Like De Grave, then, Peter Treveris apparently saw a commercial advantage in adding such images. Piet J.A. Franssen assumes that a now-lost edition of Den groten herbarius must have been published by Jan van Doesborch already around 1520, copied after De Grave's 1514 edition, and that this edition by Van Doesborch (rather than De Grave's) was the source for Peter Treveris; Franssen, Tussen tekst en publiek, 36-37, 72, and 199. Even if this were so (which is difficult to prove or refute), the fact remains that the woodcuts in The grete herball derive from a Dutch example.

24 It is not mentioned, for example, in Givens, "Illustrated Tractatus de herbis"; Blunt and Raphael, The Illustrated Herbal, 119 and 163 incorrectly state that the woodcuts in The grete herball are copied after the French Le grant herbier.

25 The vertuose boke of Distyllacyon (London: Lawrence Andrewe, 1527), 2 ${ }^{\circ}$, ESTC S106740, English translation of Hieronymus Brunschwig's Small Book of Distillation; The grete herball (London: Peter Treveris, 1529), $2^{\circ}$, ESTC S1242O7.

26 In addition to the woodcuts of plants, animals and other natural resources, Van Doesborch included numerous small scholar busts throughout his 1532 edition, which are reused by Jan Berntsz in his 1538 edition. On these images, see Andrea van Leerdam, "Talking Heads. The Visual Rhetoric of Recurring Scholar Woodcuts in a Sixteenth-century Handbook on Chiromancy," Jaarboek voor Nederlandse Boekgeschiedenis 26 (2019): 11-29.

27 Vervliet, Post-incunabula, 198; Piet J.A. Franssen, "Jan van Doesborch's Departure from Antwerp and His Influence on the Utrecht Printer Jan Berntsz," Quaerendo 18, no. 3 (1988): 163-19o.

28 Christian Coppens, “'For the Benefit of Ordinary People': The Dutch Translation of the Fasciculus medicinae, Antwerp 1512," Quaerendo 39 (2009): 193. 


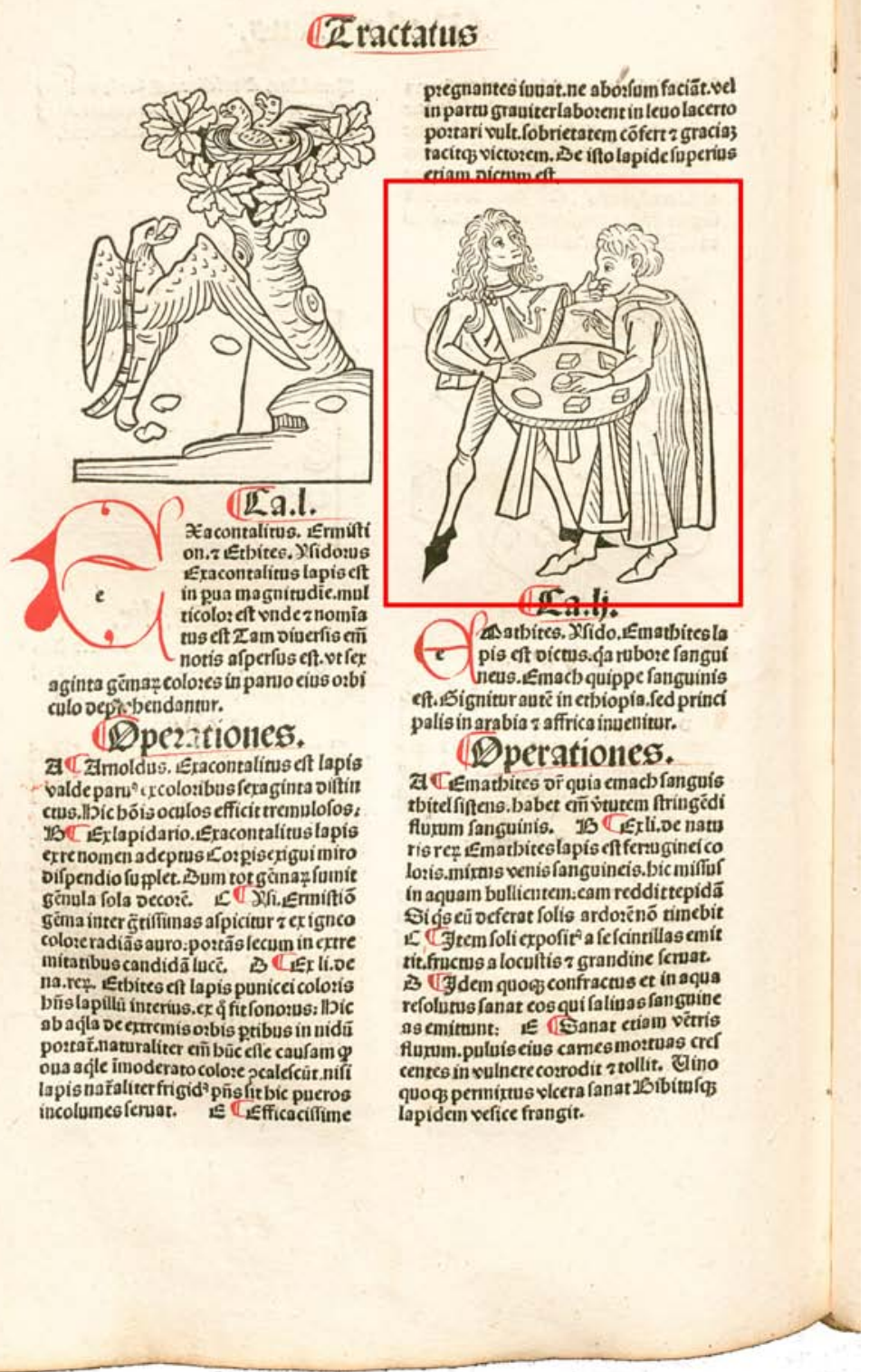

FIGURE 3A Hortus sanitatis (Mainz, Jacob Meydenbach 1491), fol. gg4v . Figures 3A-F exemplify how a narrative image from the Hortus sanitatis, showing two men at a table with lumps of a natural substance, reappears (through copied and reused woodblocks) across German, Dutch and English herbals. MUNICH, BAYERISCHE STAATSBIBLIOTHEK, 2 INC.C.A. 2576 


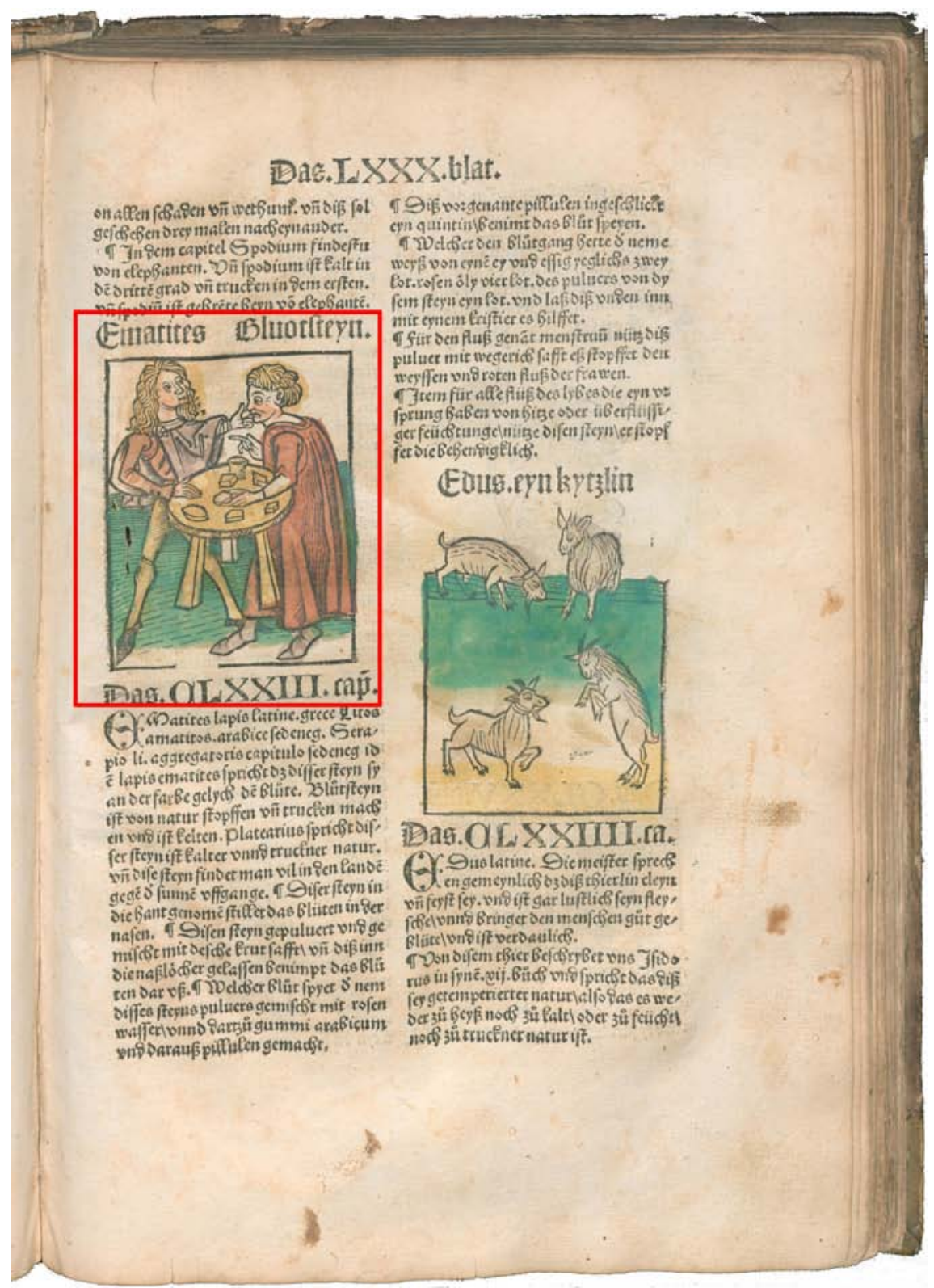

FIGURE 3B In disem buch ist der herbary (Strasbourg, Johann Prüss 1507), fol. o6 ${ }^{\mathrm{r}}$ LONDON, WELLCOME LIBRARY, EPB/D/3322 
đapolio

gute vä toille. Eñpuoer wort in menigethanoe

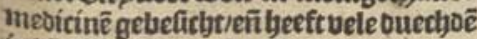

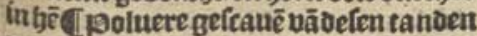
met olievärofeneñimetpoputeon ente mettuatwafcht ùmengt ghelífteē falue oftrplaeftere. Befeplaethere beilt pana viciiijoat genaemt wort oê wít Eñoitio eenfweringe in ope wortele oes nagels

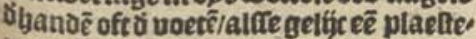
te oaer opgeleitwort. (Inaet oefen ghe

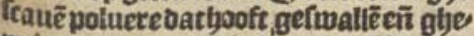

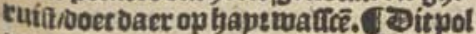
hetemet astín ingenomëbeneit oie val Ienoefucbt (1) Die oe huptuan olifantop Die bupt leghet baer oie ghichticheic ofte

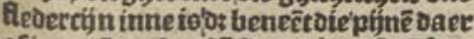

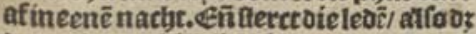
Daer gheen ghichticheirmeer inneen co. met (Olifantë beengebzanteri ghepol uerifeetr/eñ dat metter osine van eenen bock ingenomëlbsethet bêffieen in oielen Dene eñin oie blaféonoer eenighe pine. nzeroitmoet gefthien otie male achter malcanoeren (Ģ noé capitele șpooiuin vintmēoech ouechoê vanoen olifanten. âpooiumiocoutinoen oecoen graetêt

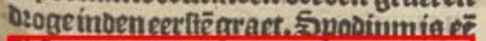
pitants been Datgebzantio

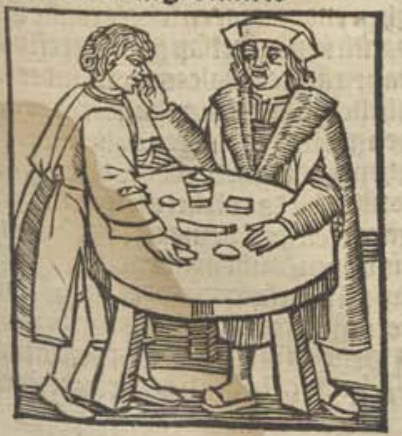

isbloetteen Ca.C.lutu T Iapis Ematites latine tptog ema thitoo grece Sconeneg arabice reta.ca.seoeneg oi.lapiocmathí

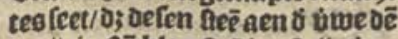

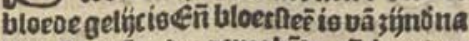
ture/Roppédelosogematiêoerefiúcouden

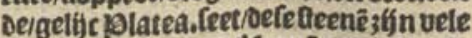
in oie lanoê oie teg ê đ̂́

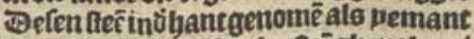

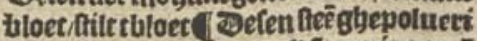

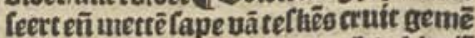

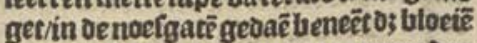
Daer wor Die bloetipuwet beneme des poluetom

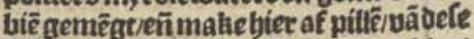
pillěeẽ orag ingenomē beneēt dat bloet

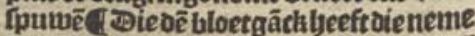

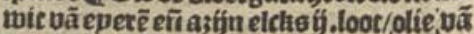
rofen iiij. loot/eñ vã déren poluere eê toot

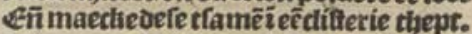

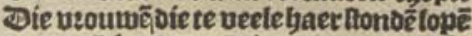

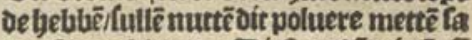

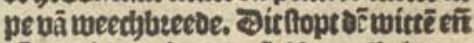
Dé toodế loopơ veoutvê. Boer alle lopen Deslíchaems' oiegrecomê stin vähittel oft vãouerulooigevuchtitibeoéfalmênuttê

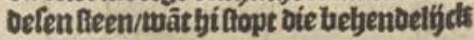

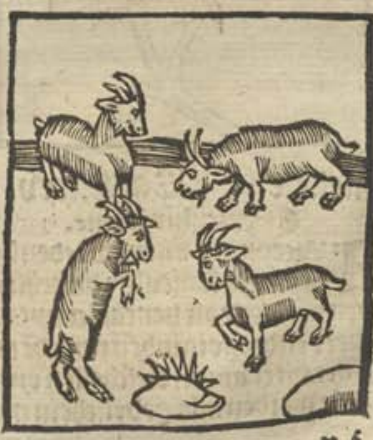

p 1

FIGURE 3C Den groten herbarius (Antwerp, Claes de Grave 1526), fol. p1 ${ }^{\mathrm{r}}$ UTRECHT, UNIVERSITY LIBRARY, MAG: RARIORA QU 133 


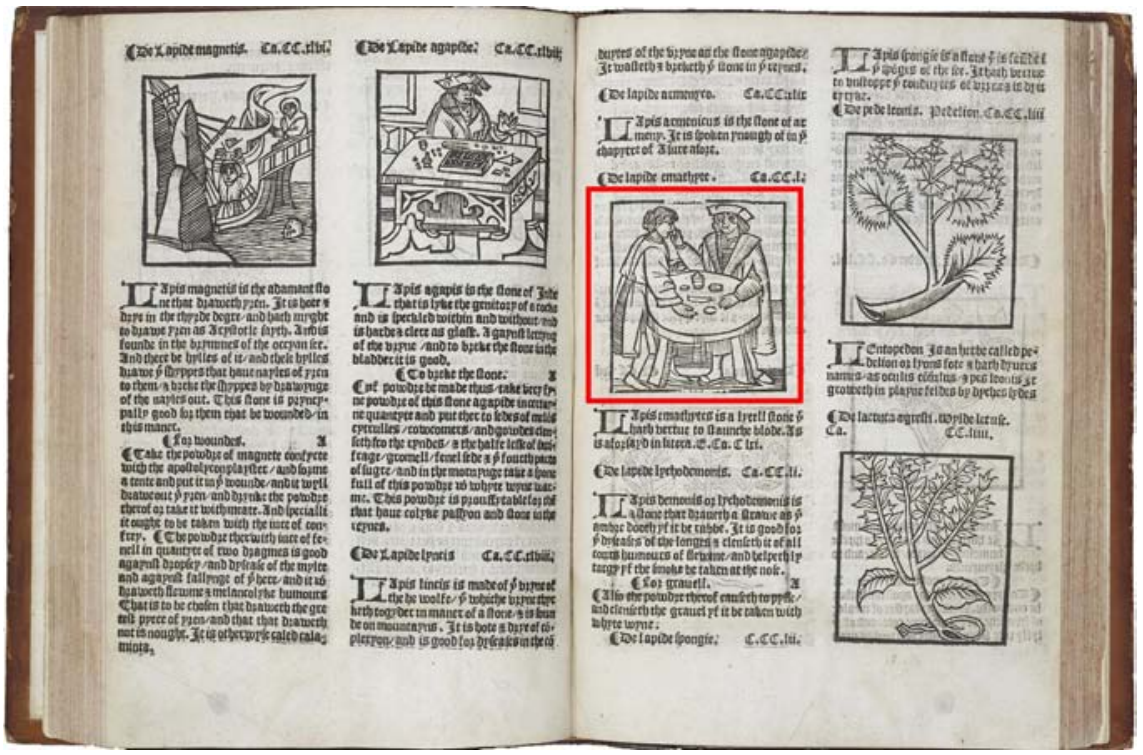

Figure 3D The Grete Herball (London, Peter Treveris 1526), fol. O6 ${ }^{r}$

LONDON, VICTORIA \& ALBERT MUSEUM, NATIONAL ART LIBRARY, 86.E.95

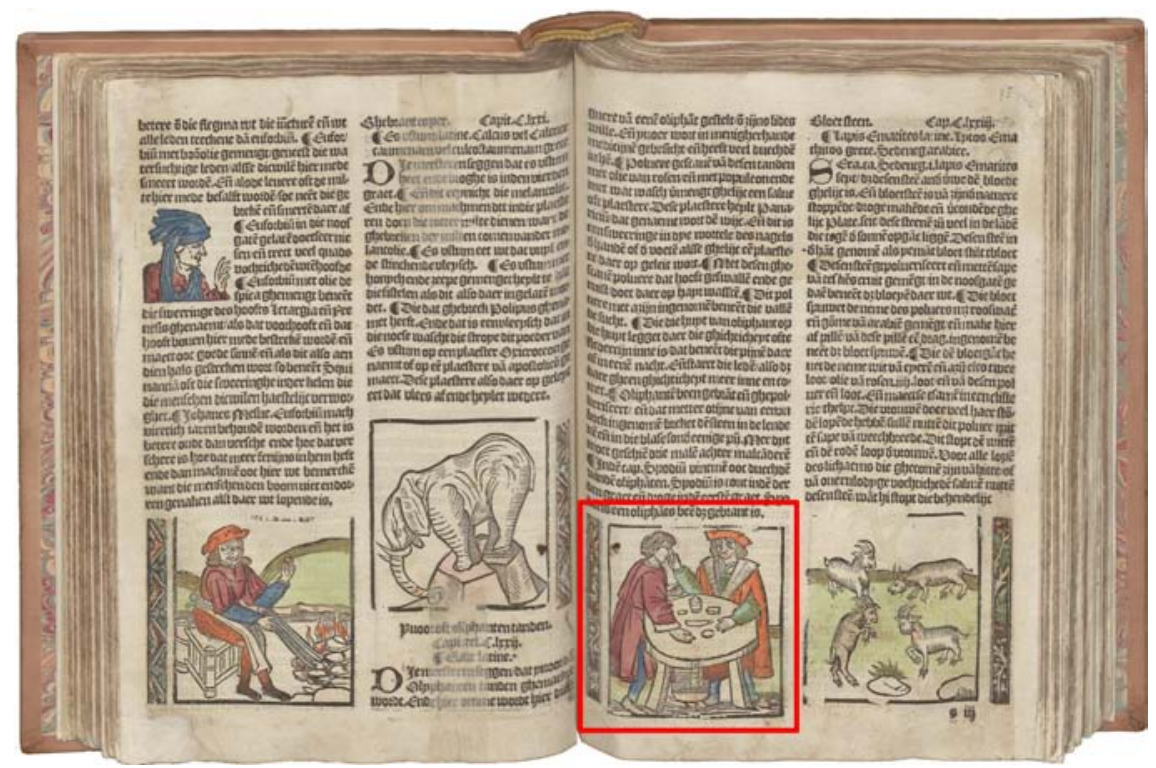

FIGURE 3E Den groten herbarius (Utrecht, Jan van Doesborch 1532), fol. s3 ${ }^{\mathrm{r}}$. Same woodblock as fig. $3 \mathrm{~d}$

ANTWERP, HENDRIK CONSCIENCE HERITAGE LIBRARY, G 142285 


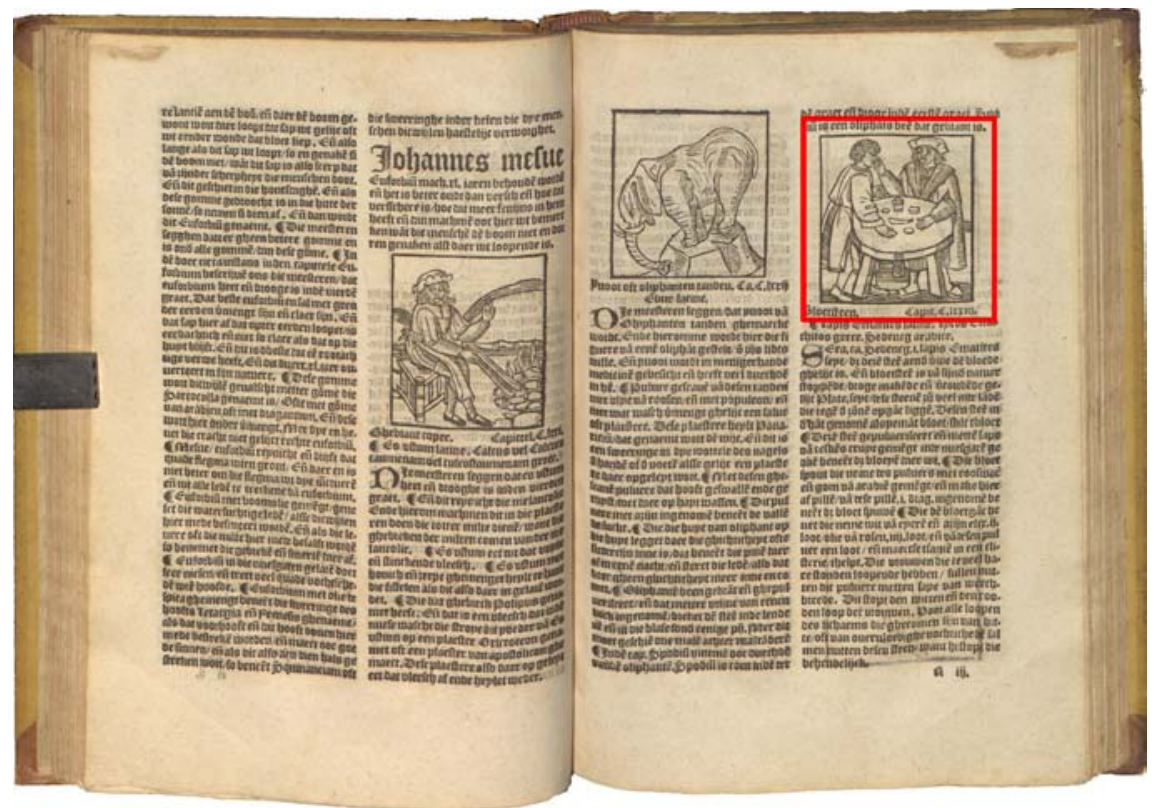

FIGURE 3 F Den groten herbarius (Antwerp, Symon Cock 1547), fol. $\mathrm{R}_{3}{ }^{\mathrm{r}}$. Same woodblock as fig. $3 \mathrm{C}$ ANTWERP, MUSEUM PLANTIN-MORETUS (UNESCO WORLD HERITAGE), R $44 \cdot 7$

\section{2 “Proper figures"?}

The combination of text from the Gart der Gesundheit and images from the Hortus sanitatis not only influenced subsequent editions, it also had implications for the claimed verisimilitude of the images. The Gart der Gesundheit has been praised by scholars as a herald of modern science because of its large number of realistic images compared to earlier herbals. ${ }^{29}$ This focus in scholarship is to a significant extent sparked by a text passage about the images in the book itself. The author of the prologue-commonly identified as Bernhard von Breydenbach (c. 1440-1497), who is assumed to have commissioned the work-explains how he took along an accomplished painter to a pilgrimage to the Holy Land,

29 William Ivins called the Gart "one of the greatest monuments in the history of the descriptive sciences"; William M. Ivins Jr., Prints and Visual Communication (Cambridge, MA: Harvard University Press, 1953), 36. Anderson, An Illustrated History, 89: "Schoeffer set ajar the gates of modern scientific publishing with the printing of Der Gart der Gesundheit." On the position of the Gart in the history of science, see also Pia Rudolph, Im Garten der Gesundheit:Pflanzenbilder zwischen Natur, Kunst und Wissen in gedruckten Kräuterbüchern des 15. Jahrhunderts (Cologne: Böhlau Verlag, 2020). 
in order to have him draw exotic plants after nature that did not grow in the German lands. ${ }^{30}$ The Dutch editions of Den groten herbarius have a literal translation of this prologue, including the truth claim about the images. This claim thus gains a different meaning, as it is now attributed to an entirely different set of illustrations.

Rather than assessing the extent of pictorial verisimilitude, I would instead like to draw attention to the paratextual rhetoric: it is noteworthy that the prologue of Den groten herbarius claims the images to have been drawn from life, whereas we know for certain that they were copied after the Hortus sanitatis (or, rather, copied after copies of the Hortus sanitatis, i.e. those in the Herbary). This image-text combination testifies to a phase of shifting ideas on the role of visual representation in the transmission of knowledge. Increasing value was attached to a discourse of reliable, lifelike images, even though the actual origin of the images might be otherwise. ${ }^{31}$ Den groten herbarius illustrates that this discourse also imbued books for a wider audience.

Regardless of how we appreciate the degree of realism, both Claes de Grave and the printers of subsequent editions of Den groten herbarius considered the illustrations to be an essential part of the book. This is emphasised by the reference to "all its figures" in the title Den groten herbarius met al sijn figueren, a reference that is not made in this way in the Gart der Gesundheit nor in the Herbary nor The grete Herball. Moreover, the figueren are again emphasised in the announcement of the prologue: "Here begins a prologue by the author of the great and proper Herbarius and of the medicines with all their proper figures." ${ }^{22}$ This caption is not copied from the Herbary but apparently added by De Grave, and retained in all subsequent editions. Thus, the trustworthiness imparted to the "proper" images, elaborated upon in the prologue, is implicitly extended to the entire book.

\section{3}

\section{Real Readers: Personalising Medical Knowledge}

As the Dutch printers ventured to appeal to readers with different levels of experience in medicine as well as in literacy, we may ask whether they suc-

30 The prologue of the Gart der Gesundheit is translated in English in Eleanour Sinclair Rohde, The Old English Herbals (London: Longmans, Green and Co, 1922), 67-69.

31 On the discourse of lifelike, "counterfeit" images that was applied to different kinds of images, and the aspirations it conveyed, see Thomas Balfe, Joanna Woodall, and Claus Zittel, eds., Advivum? Visual Materials and the Vocabulary of Life-likeness in Europe before 1800 (Leiden: Brill, 2019); Peter Parshall, "Imago Contrafacta: Images and Facts in the Northern Renaissance," Art History 16, no. 4 (1993): 554-579. 
ceeded in reaching this wide audience. Who were the owners of Den groten herbarius, and how did they use their books? This section will first look into the owners and then into patterns of use.

\subsection{Marks of Ownership}

The most immediate form of personalising a book is inscribing one's name in it. ${ }^{33}$ Of the 27 copies of Den groten herbarius I examined, fourteen contain (more or less) legible owners' names from the sixteenth and seventeenth centuries (Appendix 2). Even when we know an owner's name, however, in many cases it is still impossible to identify these persons and to find out how and why they obtained a copy of the herbal. In most cases it is not even possible to link the owner's inscription with certainty to other annotations in the same volume to learn more about their particular interests. ${ }^{34}$ Nevertheless, the list of names in Appendix 2 allows for some relevant observations with respect to the readership of Den groten herbarius.

First of all, there were both male and female owners. As various studies have shown, women played an important role in early modern healthcare and the preparation of medicines, for example in households, as local healers, in hospitals, and as medical advisors. ${ }^{35}$ For the three women listed here-Dignen van Hueculum, Magdalena van Tuerenhout, Neelken van [..]uffelsen-we do not know whether and how they were engaged in medical practices. Magdalena apparently received the book when she was still a child (copy $1526-\mathrm{N}_{53}{ }^{36}$ see Appendix 2). This suggests that the bestower wanted her to learn about materia medica from an early age and that the book was envisioned to stay with her during her lifetime. It seems to have been inherited within the family, judging from the fact that a Jasper van Tuernout also inscribed his name in it. ${ }^{37}$

33 On marks of ownership: Daniel Wakelin, "'Thys ys my boke': Imagining the Owner in the Book," in Spaces for Reading in Later Medieval England, ed. Mary C. Flannery and Carrie Griffin (Houndmills: Palgrave Macmillan, 2016), 13-33.

34 Distinguishing annotators is complicated because different hands may resemble each other, a person's handwriting may change over the course of a lifetime, and owners' names are frequently written more neatly than annotations made while reading.

35 Sharon T. Strocchia, Forgotten Healers. Women and the Pursuit of Health in Late Renaissance Italy (Cambridge, MA: Harvard University Press, 2019); Leong, "Herbals she peruseth"; Alisha Rankin, Panaceia's Daughters: Noblewomen as Healers in Early Modern Germany (Chicago: University of Chicago Press, 2013).

$36 \quad$ For the codes I use to refer to individual copies, see Appendix 2.

37 It is unclear whether Jasper's inscription is earlier or later than Magdalena's. On family ownership of recipe collections: Elaine Leong, Recipes and Everyday Knowledge. Medicine, Science, and the Household in Early Modern England (Chicago: University of Chicago Press, 2018), esp. chap. 5 . 
Secondly, the ownership marks include instances of institutional ownership. The Celestines at Heverlee (near Louvain), who numbered the books and manuscripts in their library, inscribed their copy 1514-Bo2a with shelfmark "theca 64."38 The Poor Clares in Brussels received at least two medical books from their confessor Henricus de Beringhen. Apart from the herbal (1547-A12), in which Henricus asks to pray for his soul, he also donated a copy of Tfundament der Medicinen ende Chyrurgien (printed in 1540). ${ }^{39}$ The inscription on the title page of this medical anthology details not only when it was donated (in 1555), and by whom (Confessarius huius Conuentus), but also for what purpose. ${ }^{40}$ It states that the confessor donated the book pro Consolatione infirmarum (for the comfort—or aid—of the infirm) and that it must remain in the convent's infirmary. We can imagine that the copy of Den groten herbarius served a similar practical function in the sick room of the Clares. Another copy that may have been used in an institutional medical context is $1533-\mathrm{N}_{53}$, inscribed by Coelaert Pantin with reference to a chapel of St. Nicholas. The chapel of that name in Antwerp had been founded in 1422 to care for sick and poor members of the guild of local merchants. ${ }^{41}$

Thirdly, in addition to the Celestines in Heverlee and Henricus and the sisters of St. Clare in Brussels, I found several more owners who possessed multiple books. Dignen van Hueculum, owner of 1538-Lo1, also owned a copy of Devoot ende profitelijck boecxken printed in $1539 .{ }^{42}$ Her handwriting seems to be sixteenth-century so she must have been an early owner of both volumes.

38 To my knowledge, the library of the Celestines has not been studied, but I have come across two more books from their collection with similar shelfmarks: Ms Paris, Bibliothèque de l'Arsenal, o775 ("theca $5 \mathrm{O}^{\circ}$ ), listed in Bibale: http://bibale.irht.cnrs.fr/24587, accessed February 5, 2020; and Boethius, De consolation de phylosophye (Bruges: Colard Mansion, 1477), Paris, Bibliothèque nationale de France, Rés. R. 86 ("theca 52 ").

Petrus Sylvius, Tfundament der Medicinen ende Chyrurgien (Antwerp: Willem Vorsterman, 1540), Washington, Library of Congress, Rosenwald 1159. Henricus de Beringhen also inscribed his name in two manuscripts with sermons by Bernard of Clairvaux: Joseph van den Gheyn, S.J., Catalogue des manuscrits de la Bibliothèque royale de Belgique, 13 vols. (Brussels: Lambertin, 19o1-1948), vol. 2 (1902) nr 1464 and vol. 3 (1903) nr. 1874.

40 The initials "P.H.B.," written in a printed shield in the centre of the page, likely refer to "pater Henricus de Beringhen."

41 Agentschap Onroerend Erfgoed 2020, "Sint-Niklaasgodshuis," https://id.erfgoed.net/erf goedobjecten/535o, accessed February 5, 2020.

42 Een devoot ende profitelijck boecxken (Antwerp: Symon Cock, 1539), Haarlem, Stadsbibliotheek, $176 \mathrm{~K}$ 9. Dignen's ownership of this work is discussed in Jeske van Dongen, Een devoot ende profitelijck boecxken. Terug naar de bron (dissertation Radboud Universiteit Nijmegen, 2011), https://repository.ubn.ru.nl/bitstream/handle/2066/91299/91299.pdf, accessed February 5, 2020, 35-37. Van Dongen does not mention Den groten herbarius. 
Petrus Saxsi, who wrote his name in his herbal (1526-Lo1) in 1642, over a century after its publication, also owned a surgery manual in Dutch from 1535. His ownership and annotation of these books suggests that he had a more than passing medical interest. ${ }^{43}$ Lambertus Optio $\left(1583^{-c}\right.$. 1619), the son of the secretary of Amsterdam and owner of 1514-LMB, must have been a highly literate man: he wrote two chronicles of the city of Amsterdam, one of which-written together with his father-includes his own family history. ${ }^{44}$ There he mentions a Willem Barentsoen who was the uncle of his mother. This Willem Barentsoen has inscribed his name in the same herbal. Like the copy of the Van Tuerenhouts, the herbal thus seems to have been handed down within the family, probably after Willem's death (before 16o1).

Finally, marks of ownership sometimes refer to book owners' professional occupations. As recent studies show, such inscriptions indicate that professional occupation constituted an important aspect of how readers constructed their identities. These references also testify to a conception of the book as a socially embedded object: identifying oneself is relevant as the book may (and eventually will) end up in someone else's hands. ${ }^{45}$ I found only one case where the owners identify themselves as medical practitioners: the binding of 1533-N53 has a seventeenth-century stamp of the Surgeons' College in Bruges. Other owners of Den groten herbarius in my study apparently either did not have a medical professional identity, or they did not consider their engagement with health matters as their primary identity. ${ }^{46}$ Jasper van Tuernout (1526-N53) identifies himself as brewer, Loys de Joncheere (1514-Bo2b) as bailiff

43 Hieronymus Brunschwig, Dits dat hantwerck der cirurgien (Utrecht: Jan Berntsz, 1535), London, British Library, 549.k.4, ownership mark on fol. D1 ${ }^{\mathrm{r}}$. In this case, some annotations can be clearly attributed to Petrus Saxsi: both volumes he owned include typical "NB" marks (nota bene) with both letters merged.

P. Scheltema, Aemstel's oudheid of Gedenkwaardigheden van Amsterdam, vol. 3 (Amsterdam: Scheltema, 1859), V-VI, 35-37; "Opsy," in Nieuw Nederlandsch Biografisch Woordenboek, ed. P.C. Molhuijsen and P.J. Blok, 10 vols. (Leiden: A.W. Sijthoff, 1911-1937), vol. 5 (1921), col. 405-406. Lambertus is thought to have been a merchant or a ship owner.

45 Wakelin, "Thys ys my boke," esp. 25-27; Margriet Hoogvliet, “'Pour faire laies personnes entendre les hystoires des escriptures anciennes.' Theoretical Approches to a Social History of Religious Reading in the French Vernaculars During the Late Middle Ages," in Cultures of Religious Reading, ed. Sabrina Corbellini (Turnhout: Brepols, 2013), 266-267.

46 In other medical books in Dutch, studied in my $\mathrm{PhD}$ research, owners' references to medical professions are equally rare. I found just two inscriptions by owners who identified themselves as medical practitioners, in both cases surgeons: Fasciculus medicine (Antwerp: Claes de Grave, 1512), Copenhagen, Royal Library of Denmark, 40 Med. 5085o, barcode 20002334); Tscep vol wonders (Brussels: Thomas van der Noot, 1514), Brussels, Royal Library of Belgium, LP 15.963 A. 
and ontfangher (receiver) of Watervliet and Waterdijck, and, as we already saw, Henricus de Beringhen (1547-A12) emphasises his role as confessor of the convent of St. Clare. This latter occupation apparently involved not only care for the soul, but also for the physical health of the sisters. Although the lack of references to medical backgrounds complicates our understanding of why these people owned an herbal, the overview of owners does point to a wide array of institutional, civic and domestic contexts in which Den groten herbarius was used. Based on this material, then, we may conclude that the printers of Den groten herbarius succeeded in reaching a wide audience.

\subsection{Reading Practices}

Apart from owners' marks, other annotations can also be regarded as acts of personalisation: early modern readers customised their books driven by their own goals, interests, and habits. The examined copies of Den groten herbarius, listed in Appendix 2, contain traces from many more readers than those who inscribed their names. Although the authors of the vast majority of annotations remain anonymous, both the content and the appearance of the annotations provide indications of how these readers approached and used their herbals. Before zooming in on three particular ways of customisation, I briefly provide some general observations.

While some copies of Den groten herbarius are more substantially annotated or worn than others, it is noteworthy that nearly all of them contain at least some early modern traces of use. Many of the annotators seem to share a predominantly practical interest in the remedies described in the text. The majority of marks and annotations pertain to recipes. Margins and endleaves have been used frequently to write down additional recipes. Contrarily, annotations are much rarer in the additional treatises on other topics such as uroscopy and trees.

Another indication of practical interests in remedies is that the indexes contain many annotations to retrieve remedies more easily. For example, names of substances have been inscribed in the head-to-feet index, and chapter numbers have been corrected. In at least half of the surviving copies, the first and last quires, containing the title page, table of contents and indexes, are dirtier or more damaged than the rest of the book (frayed edges, paper restorations), and in several cases these first or last leaves are lacking altogether. ${ }^{47}$ These non-

47 Lacking first pages for example in 1514-Ao4, 1526-Uo1, 1538-Co1; damaged or smudged first and/or last pages for example in 1532-A170, 1538-Lo1, 1547-Lo1. See also Appendix 2. 
textual traces of use suggest that some readers had literally used up the outer parts before the volumes received their present bindings. ${ }^{48}$

Despite such damages and losses, the volumes were cherished and preserved as personal repositories of medical knowledge. This is suggested both by the multitude of annotations throughout the volumes and the testimonies of family ownership discussed above. Judging from the annotations, seventeenthcentury readers like Petrus Saxsi continued to use the herbals out of pragmatic rather than antiquarian interests.

Annotators each have their own particular ways of marking and modifying their books. Nevertheless, certain conventions clearly come to the fore when examining a substantial number of copies. In what follows, I will discuss three of these conventions that enrich our understanding of how herbals were used: tagging remedies and plant names, attaching pins to the pages, and colouring woodcuts.

\subsection{Tagging Remedies and Plant Names}

The most common ways of marking text passages-in Den groten herbarius as perhaps in any early modern book-are underlining, writing nota or nota bene, or drawing pointing hands (manicules) in the margins. In addition, a pervasive type of marking in the herbals on which I want to focus here is what I call tagging: writing down keywords that attract attention through their positioning on the page, often in the margin. Two kinds of information are tagged most often, as I will discuss: the workings of remedies, and plant names.

To summarise a remedy, readers write, for example, "for the eyes" or "to stop bleeding" or "against pestilence" in the margin, repeating keywords from the printed text. Such marginalia offer visual grip on the page to retrieve certain recipes more easily. Many of the recipes annotated in this way reveal an interest in everyday ailments such as toothache, bad or sore eyes, menstrual pains, fever, colds, and wounds. ${ }^{49}$ Various readers also show a concern with "pestilence," which could refer to the plague but also to epidemic diseases more generally. Some keywords reflect quite particular interests. In 1514-Bo2a, several annotations are related to conditions that affect the mind, including melancholy, drunkenness, and delusions, as well as to sexual lust and to warding off devils. In 1538-Co1, various recipes against nosebleeds have been tagged, and one

48 Of the 27 examined copies, four have a pre-18th-century binding: $1526-\mathrm{N}_{53}, 1533-\mathrm{N}_{53}, 1538$ Co1, 1547-Go3. All other bindings are more recent.

49 On readers' interest in remedies for common ailments, see also Paul Slack, "Mirrors of Health and Treasures of Poor Men:The Uses of the Vernacular Medical Literature of Tudor England," in Webster, Health, Medicine and Mortality, 263-264. 
annotator (1514-Ko7) apparently had a particular interest in buzzing ears. Such a specific focus does not preclude professional use of the book, but it rather seems to point to a more personal interest of a reader in an ailment from which he/she or someone in the direct vicinity was suffering. In a dozen of copies, some recipes have also been marked with a "+"-symbol, especially in indexes, perhaps to highlight the ones that were considered effective.

Apart from the subject matter, the language in which the recipe keywords have been written also reveals something of readers' backgrounds. By far the majority of keywords are in Dutch, like the printed text. Keywords in Latin also occur frequently. Some readers apparently switched effortlessly between both, even combining them in a single annotation like contra febres ende quade mage (against fever and a bad stomach)..$^{50}$ One annotator had a particularly graphic way of tagging (1526-N53): this reader combined written keywords (in Dutch) with tiny marginal drawings of the body parts to which the recipes pertained (Fig. 4). The drawings include many eyes, but also ears, breasts, feet, penises, and a vomiting man. Overall, the predominance of annotations in Dutch and, to a lesser extent, Latin, indicates that the vernacular herbals were mostly read by people who preferred to read as well as write in the vernacular (probably their mother tongue), but that the "learned" readers to whom the prologue refers also made intensive use of these books.

A second type of tagging that is typical of herbals is the inscription of plant names. ${ }^{51}$ The printed chapter titles of Den groten herbarius provide the names in Dutch, with the Latin, Greek and Arabic names immediately following. Readers repeat the Dutch or Latin name, or they add a locally used alternative. They commonly use either the chapter title or the woodcut at the beginning of the chapter to visually anchor the added name, in several cases even writing inside a woodcut's framing border (cf. Fig. 7). ${ }^{52}$ In all six

$50 \quad 1514-\mathrm{Ho} 4$, fol. b5 5 . Other languages are used occasionally: 1538-Co1 contains keywords in English. 1526-Lo1 contains annotations in Low German or perhaps Danish, including the owner mark of Petrus Saxsi.

51 Providing synonyms, both in Latin and vernaculars, for a single plant species was a widespread practice in the pre-Linnean era due to the lack of consistent nomenclature. Florike Egmond, "Names of Naturalia in the Early Modern Period: Between the Vernacular and Latin, Identification and Classification," in Translating Knowledge in the Early Modern Low Countries, ed. Harold J. Cook and Sven Dupré (Zurich/Berlin: LIT, 2012), 131-162. Anna Pavord, The Naming of Names: The Search for Order in the World of Plants (New York: Bloomsbury, 2005).

$5^{2}$ For example in 1514-Bo2b, the chapter on ivory is illustrated with a woodcut of an elephant, captioned twice by a sixteenth-century reader: the word Elephas is written once inside the woodcut's border and again in the margin next to the woodcut. 


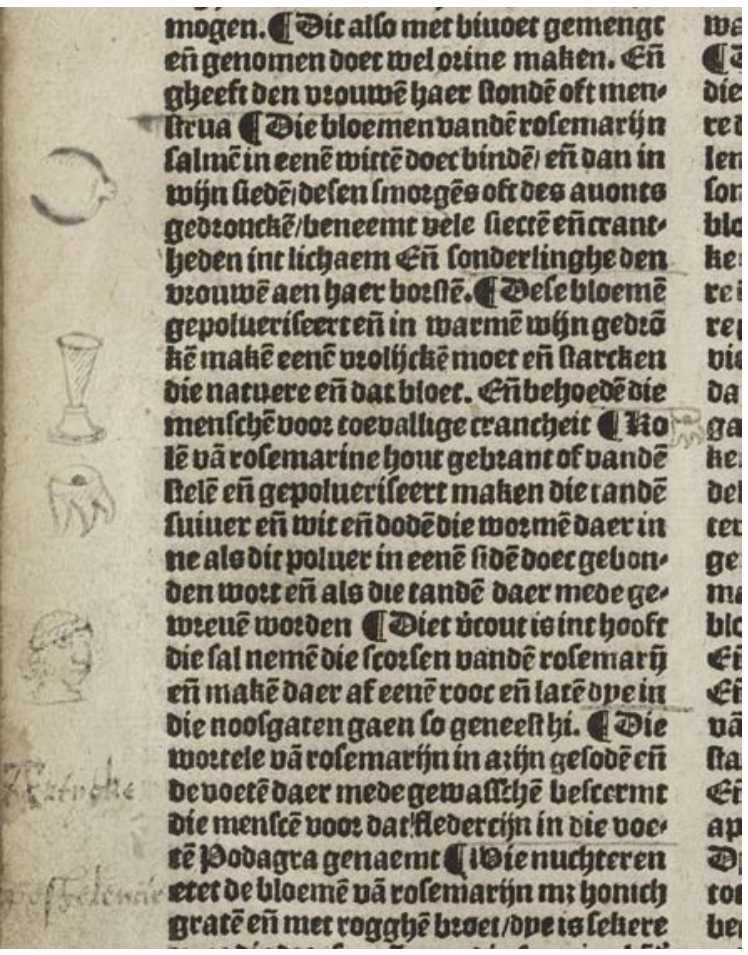

FIGURE 4

Marginal drawings highlighting the efficacy of recipes in Den groten herbarius

(Antwerp, Claes de Grave 1526)

NEW YORK, METROPOLI-

TAN MUSEUM OF ART, 44.7.33, FOL. C3 ${ }^{\mathrm{V}}$. PHOTO:

(C) 2021 THE METROPOLITAN MUSEUM OF ART/ART RESOURCE/SCALA, FIRENZE

editions, the woodcut illustrating a chapter precedes the text of that chapter (and in most cases it also precedes the chapter title). Therefore, the woodcuts are eye-catching navigational aids, signalling the start of a new chapter even more conspicuously than the chapter titles. The way readers have added handwritten plant names suggests that they recognised and used this function of the woodcuts..$^{53}$ The combination of an image and a familiar name will have helped a reader to easily recognise what plant is discussed. This practice shows that not just the content but also the mise-en-page of annotations is important to take into account when studying reading practices; in this case it helps to shed light on how early modern readers looked at, and used, images. ${ }^{54}$

53 A clear example is the keyword muis ore written in 1533-B16 to mark the chapter on Muis oere (Auricula muris or Anagallus in Latin): the keyword is written below the woodcut for this chapter, which is at the bottom of fol. $\mathrm{c}_{5}^{\mathrm{r}}$, while the chapter title and the chapter itself follow on fol. $\mathrm{c}^{\mathrm{v}}$. The reader thus anchored the annotation to the woodcut rather than to the printed text.

A strong plea for closer attention to visual aspects of annotations is made by William 
Specific, pragmatic interests seem to be reflected in this naming practice. In the copies I examined, names or synonyms are never provided for all plants, but for several dozen at most, often spread throughout the book. We are left to guess whether a reader's interest was directed towards the medicinal powers of the plant, its familiarity, or its exotic nature. One sixteenth-century reader has tagged both the native daisy (Kerssauwe) and the more exotic elephant that illustrates the chapter on ivory (1514-Bo2b). Such keywords also function as translations, adding the name for a plant as it was apparently current, or better recognisable, in the reader's local context. Even when we do not know why a reader has provided synonyms for certain plants, we may interpret this practice as a way in which readers relate knowledge from the book to their own social environment. Whether the plant names function as structuring aids, mnemonic aids, means of appropriation, expressions of practical relevance or of personal curiosity, readers use the woodcuts or chapter titles as visual landmarks on the page to which they could attach these keywords.

\subsection{Pins on the Page}

The second practice of personalisation to be discussed, which has received little study as yet, is the attachment of pins to the pages. While pins and traces of pins are much more rare than written keywords, they are decidedly more embedded in early modern reading practices than has been acknowledged so far. In most cases the actual pins have been removed, but their former presence in the margins of a page is evident from tiny, aligned holes with a rusty stripe between them. Of the 27 examined copies, five contain traces of pins, and in three of these a pin is still present. ${ }^{55}$ These pins show a greater or lesser degree of oxidation, which explains the rust traces on the paper (Fig. 5). Based on their positioning, and on cases encountered in other volumes, pins seem to have served two main functions: either as paperclips, or as markings.

The use of pins comparable to present-day paperclips is known from early modern personal archiving practices. Attaching documents to each other, pins provided a flexible archiving system that allowed for an easy rearrangement or removal of certain papers. ${ }^{56}$ It seems plausible at least for a few of the pins in

H. Sherman, "The Reader's Eye," in Biographien des Buches, ed. Ulrike Gleixner, Constanze Baum et al. (Göttingen: Wallstein Verlag, 2017), 23-38.

Moreover, 1514-Bo2b contains a piece of thread sown through fol. k6. In my $\mathrm{PhD}$ research I found nearly a dozen copies of other Dutch medical works, too, that contain threads and/or pins, including for example Tfundament der medicinen ende chirurgien (Antwerp: Willem Vorsterman, 1532), Copenhagen, Royal Library of Denmark, Fol. Pat. 19840, which contains both threads and pins.

$5^{6}$ Jane Giscombe, "The Use of Pins in Early Modern England (1450-1700)," The Book \& 

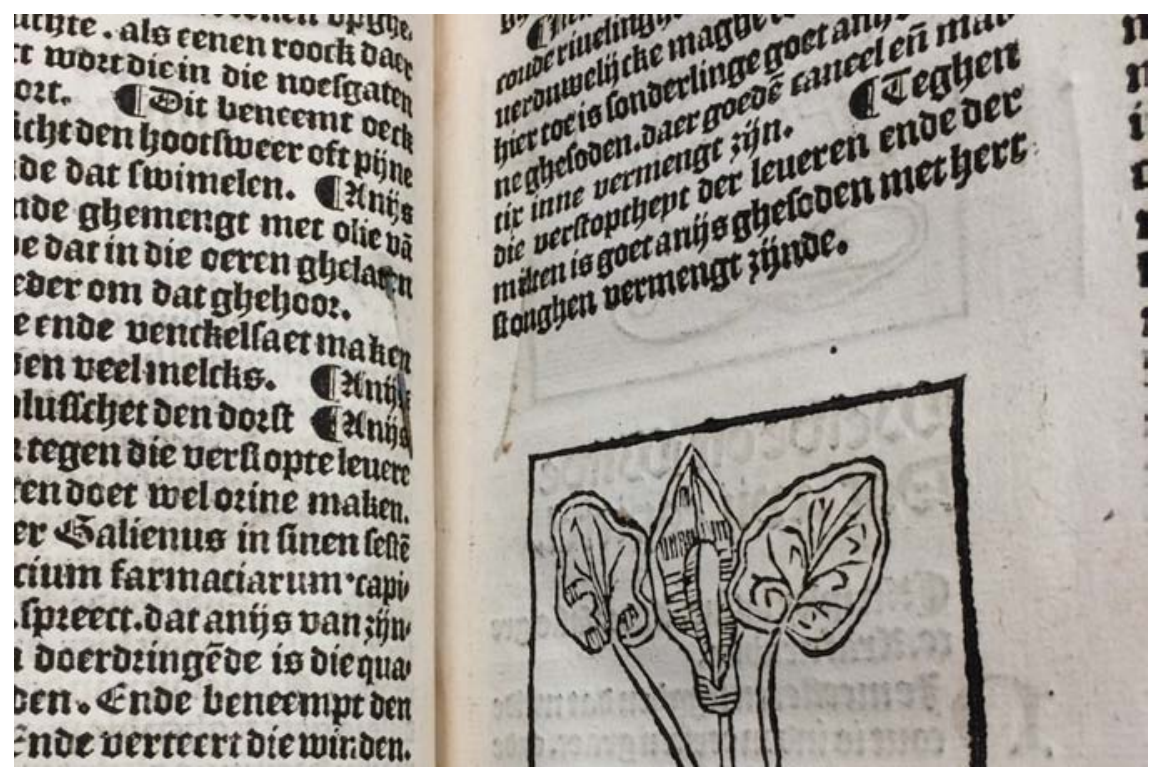

FIGURE 5 An oxidated pin and its offset on the facing page in Den groten herbarius

(Antwerp, Claes de Grave 1514)

ANTWERP, MUSEUM PLANTIN-MORETUS (UNESCO WORLD HERITAGE),

R 46.7 , FOLS. B $4^{\mathrm{V}}-\mathrm{B} 5^{\mathrm{R}}$

my corpus that they were used in this way, even though whatever they attached is now lost. ${ }^{57}$ On one of the pages of 1514 -Ho4, three traces of pins are visible in the margin, placed in parallel and very close to each other. Possibly these pins jointly held something that would otherwise tear loose. For an herbal it seems feasible that pins could also be used to attach dried plants to a page, although I have not yet come across any examples of such a practice. ${ }^{58}$

Paper Gathering, May 31, 2018, https://thebookandpapergathering.org/2018/o5/31/the-use -of-pins-in-early-modern-england-1450-170o/, accessed February 9, 2020. Elaine Leong, “Read. Do. Observe. Take Note!," Centaurus 6o, no. 87 (2018): 96-98. Malcolm Walsby, "Cheap Print and the Academic Market: The Printing of Dissertations in SixteenthCentury Louvain," in Broadsheets: Single-sheet Publishing in the First Age of Print, ed. Andrew Pettegree (Leiden: Brill, 2017), 371-373.

57 A copy of Leonhart Fuchs, Den nieuwen herbarius (Basel: Michael Isingrin, 1545 or later) at Utrecht University Library, ALV 162-459, still contains many paper slips with notes pasted on or, in two cases, pinned to the pages. Jessie Wei-Hsuan Chen and Andrea van Leerdam, "Densely Annotated and Richly Illustrated: A Famous Herbal in Dutch Translation" (Utrecht, University Library, 2017), https://www.uu.nl/en/utrecht-university-library -special-collections/collections/early-printed-books/popular-printed-material/den-nieu wen-herbarius-1545, accessed April 12, 2021.

$5^{8}$ The dried plants I have come across so far were inserted loosely between the pages, or 
The surviving pins are fixed so tightly and meticulously to the pages that we may wonder how something else could ever have been attached to them without leaving a trace. Another possibility is that some pins functioned as reading marks, similar to keywords or pointing hands, as a means of structuring and/or a mnemonic aid. John Brinsley in his Ludus Literarius; or, The Grammar Schoole (1612) provides advice on how to annotate difficult passages, or passages of special interest. Brinsley advises underlining or "some prickes, or whatsoeuer letter or marke may best helpe to cal the knowledge of the thing to remembrance." 59 One copy of Den groten herbarius (1526-N53) with various pins and traces of pins includes pinholes next to the only passage that is underlined in red and that was apparently considered of special importance. A close look at the positions of the pins, then, might provide indications of their functions. While many are carefully pinned in the margin, exactly parallel to the printed text and frequently right at the beginning of a chapter or paragraph, some are pinned right through the text. ${ }^{60}$ The marginal ones may well have functioned as reading marks, while for the ones on the text a function as paperclip is more likely.

\subsection{Colouring}

Like tagging and using pins, the practice of hand-colouring images is also revealing of the ways in which readers approached their books. The addition of colour in plant images can have epistemic significance, as it can render the images more realistic or more recognisable. Moreover, colouring is an eyecatching means of personalising a book. Scholarship has focused on the role of professional colourists in the production of prints. ${ }^{61}$ Susan Dackerman has rightfully observed that "color was often integral to the conception and mean-

pasted or sown on the page. I thank Julia Heideklang and Sabrina Minuzzi for sharing their findings of dried plants in early modern herbals with me. For some examples: Chen and Van Leerdam, “Densely Annotated," Olariu, “The Misfortune," 54; Ursula Rautenberg, "Das Buch als Artefakt und kommunikatives Angebot. Die Exemplargeschichte des Herbarius latinus (Mainz: Peter Schöffer, 1484) aus der Bibliothek des Christoph Jacob Trew," in Gleixner et al, Biographien des Buches, 73 and Tafel vi (443).

59 Quoted in William H. Sherman, Used Books. Marking Readers in Renaissance England (Philadelphia: University of Pennsylvania Press, 2008), 4.

6o For example in 1514-A12, one pin is still present, pinned through the text (fol. b4).

61 Susan Dackerman, Painted Prints. The Revelation of Color in Northern Renaissance and Baroque Engravings, Etchings, and Woodcuts (University Park, PA: Pennsylvania State University Press, 2002), esp. 15-26. Truusje Goedings focuses on professional colouring but also discusses 17 th-century colouring by "amateurs;" Truusje Goedings, 'Afsetters en meester-afsetters': de kunst van het kleuren 1480-1720 (Nijmegen: Vantilt, 2015). 
ing of printed images." ${ }^{2}$ Often, however, colour in the copies of Den groten herbarius seems to have been added by readers themselves rather than by professional colourists. As a consequence, colouring touches upon issues of production as well as reception.

Of the 27 copies, eleven have some amount of hand-colouring, but the ways in which woodcuts were coloured vary greatly. In 1532-A170 every single woodcut has been coloured, even including the numerous printed initials and decorative borders. While this may very well have been done by a professional colourist, it is unlikely that a professional would have done such a meagre job as the mere three partially coloured woodcuts in 1538-Lo1. Equally nonprofessional is the colouring in $1547-$ Go3, where hardly any colours have been used but two or three shades of green, applied to roughly a third of the images, scattered throughout the book. ${ }^{63} \mathrm{~A}$ woodcut like that of strawberries clearly shows that this reader simply did not have more colours at his or her disposal: the leaves and stems of the strawberry plant are neatly coloured green, but the strawberries themselves are left uncoloured (Fig. 6). The dispersed addition of colour may testify to an interest in specific plants, or maybe the reader simply added it in distraction, as a kind of doodling. Other readers, on the other hand, show great skill in colouring. Copy 1532-B16 has been coloured with great precision, rich detail and an impressive array of colours. Again, however, this must have been done by a reader rather than a professional colourist. Two of the colours, bright red and deep blue, have also been used to rubricate the text as well as to add manicules, nota and other traces of reading (Fig. 7). In looking at coloured prints, we need to be alert, then, to signs of professional or "amateur" colouring, and we need to be aware that the boundaries between production and reception are not clear-cut. ${ }^{64}$

In most copies, the colours applied in plant illustrations can be qualified as naturalistic, as they more or less resemble the colours of the living plants. Readers' and/or colourists' choices of colours thus reflect a similar concern with "counterfeit," truthful images as expressed in the prologue. One lavishly coloured copy (1514-Ko7), however, shows greater concern with embellishment than with verisimilitude. The colourist seems to have delighted in showing off his or her skilled use of a wide range of colours, regardless of whether they are

\footnotetext{
62 Dackerman, Painted Prints, 11.

63 At least one of the green shades is now suffering quite badly from a kind of oxidation: it has discoloured to a heavy brown that has seeped through the paper.

64 Although I agree with Dackerman that the artists who coloured prints deserve more attention (Painted Prints, 15), my point here is that we should also pay closer attention to other colourists than professional artists.
} 


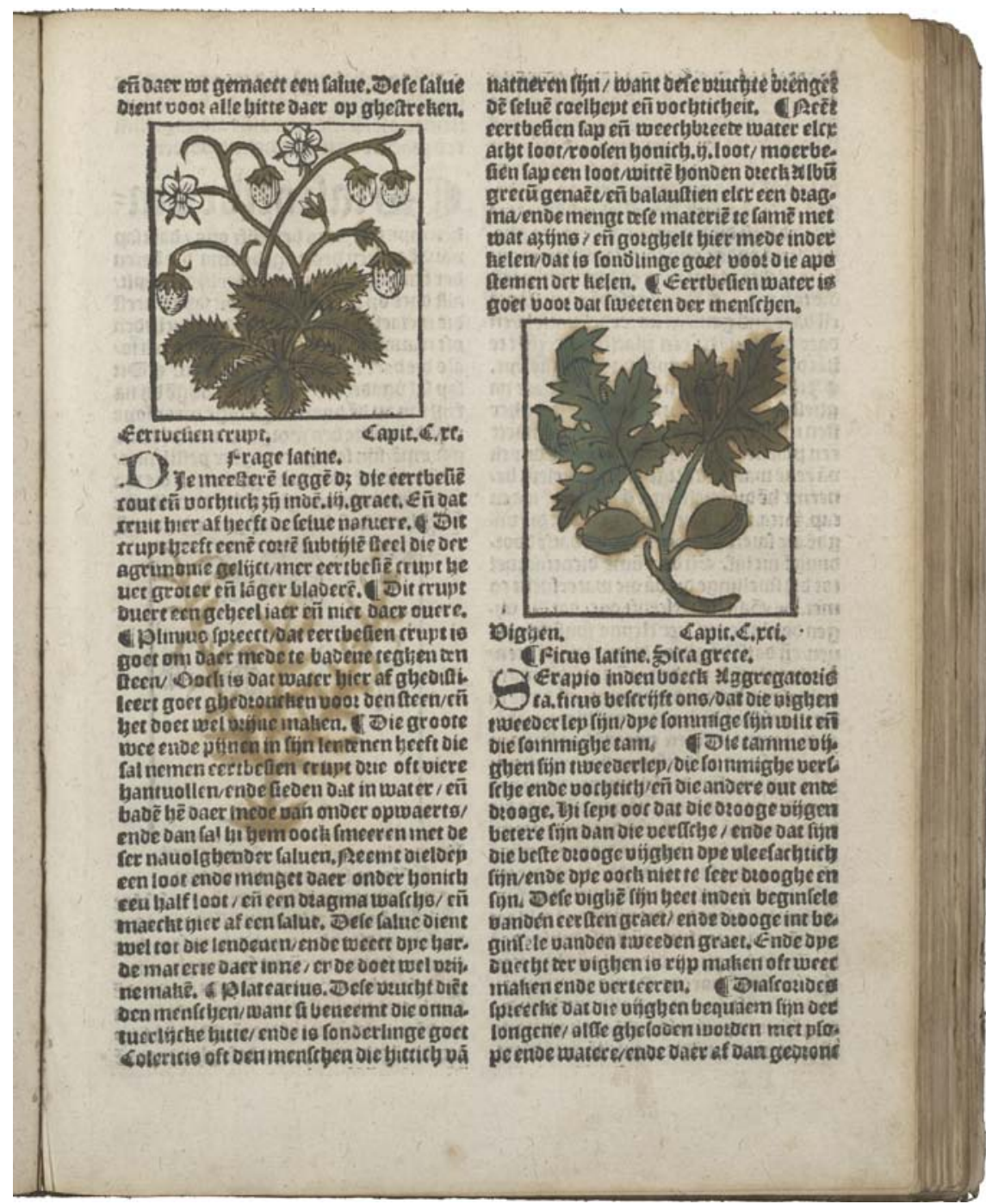

FIGURE 6 Hand-colouring with a limited pallette in Den groten herbarius (Antwerp, Symon Cock 1547)

GHENT, UNIVERSITY LIBRARY, BIB.ACC.0O3404, FOL. S4 ${ }^{\text {R }}$

naturalistic. A single flower of the peonie is coloured with red, blue, pink as well as yellow petals, and the clary sage and several other flowers are similarly multicoloured (Fig. 8). The presence of colour in itself may have conveyed a book's value and importance, even in partially coloured copies. ${ }^{65}$

65 As Dackerman observes with respect to hand-colouring around 1500, "the appearance of 


\section{4}

\section{Conclusion}

The surviving editions and individual copies of Den groten herbarius offer a coherent and comprehensive case to examine the functioning of an illustrated herbal from the perspective of book producers' intentions in relation to the perspective of actual use. The book producers' popularising strategies not only manifest themselves in paratexts like title page and prologue, but also in the choice of a more narrative, eventful kind of illustrations than those in the Gart der Gesundheit from which the text was translated. This choice positions Den groten herbarius as a link between German and English herbals. Its textual emphasis on "proper," lifelike images reflect a growing appreciation of the epistemic roles of images, even when the images themselves do not necessarily live up to the claims.

Judging from the early modern owners' marks and traces of reading in the 27 examined copies, the book producers succeeded in reaching people from different backgrounds with different interests, both the "learned" and the "unlearned." Among the owners are both men and women, and the book was used in institutional as well as private settings. The overwhelming majority of these owners do not identify themselves as medical practitioners, suggestingand in some cases explicitly indicating - that their primary identity was otherwise. Some may indeed have used the herbal as a do-it-yourself medical handbook, as the later editions suggest on their title pages.

Analysing a substantial group of individual copies proves crucial for a more contextualized interpretation of users' traces that might seem idiosyncratic at first. The attachment of pins to the pages, either as paperclips or as reading marks, turns out to be a more widespread practice than has been acknowledged so far. The same is true for readers doing their own colouring of woodcuts. An alertness to such practices is important to deepen our understanding of how early modern readers engaged with their books, or even specifically with images. Moreover, the mise-en-page of traces of use proves a valuable-and as yet underused - source to study reading practices. The positioning of pins and plant names, for example, offers insight into how readers conceived of the page as a visual space.

A key pattern emerging from the traces of use is the predominant interest in medical recipes, especially against everyday ailments. This interest continued until well into the seventeenth century. Even though the field of botany

the color itself was valued over the meticulousness of its application." Dackerman, Painted Prints, 9. 


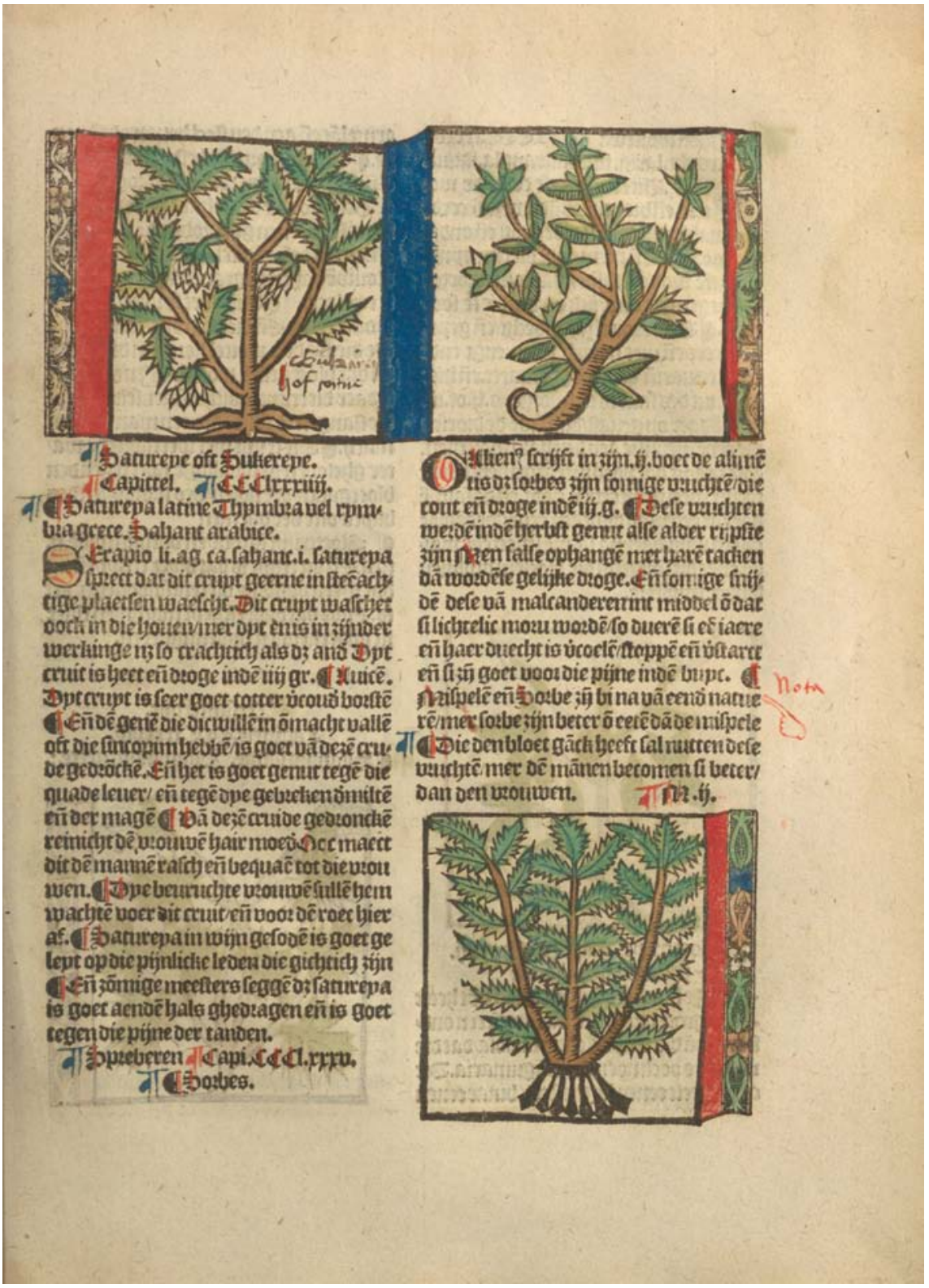

FIGURE 7 The same hues of red and blue used for colouring, rubricating and annotating in Den groten herbarius ([Utrecht,] Jan van Doesborch 1532) BETHESDA (MD), NATIONAL LIBRARY OF MEDICINE, HDM COLLECTION, WZ 240 I38DU 1536, FOL. M2 ${ }^{\text {R }}$ 


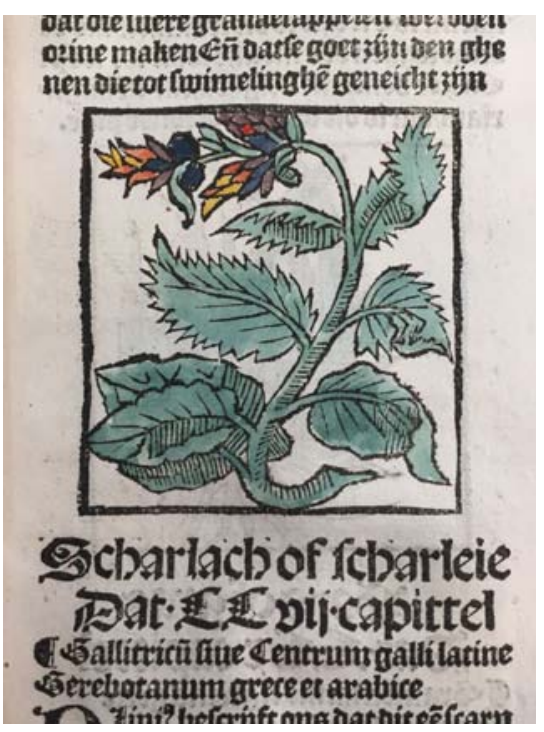

\section{FIGURE 8}

Multicoloured flower of clary sage in Den groten herbarius (Antwerp, Claes de Grave 1514)

COPENHAGEN, ROYAL LIBRARY OF DENMARK, $4^{\circ}$ FARMAKOGNOSI (CUBA), FOL. R $5^{\text {R }}$

had gone through great developments in the sixteenth century, with first-hand observation and practices of visualisation taking up new roles, these shifts were evidently not a central concern to all readers of herbals. Several of these early printed works continued to function for many decades as personalised, sometimes family-owned reference works of medical knowledge.

\section{Abbreviations}

ESTC English Short Title Catalogue, https://estc.bl.uk

GW Gesamtkatalog der Wiegendrucke, www.gesamtkatalogderwiegendruc ke.de

ISTC Incunabula Short Title Catalogue, https://data.cerl.org/istc

NB Malcolm Walsby and Andrew Pettegree, Netherlandish Books. Books Published in the Low Countries and Dutch Books Published Abroad Before 1601 (Leiden: Brill, 2010)

NK Wouter Nijhoff and M.E. Kronenberg, Nederlandsche bibliographie van 1500 tot 1540 (The Hague: M. Hijhoff, 1923-1971), 3 vols.

USTC Universal Short Title Catalogue, www.ustc.ac.uk

VD 16 Verzeichnis der im deutschen Sprachbereich erschienenen Drucke des 16. Jahrhunderts, www.vdi6.de 


\section{A.1 Appendix 1: Editions of Den groten herbarius}

- Den groten herbarius met al sijn figueren, Antwerp, Claes de Grave 17 June 1514, $2^{\circ}$, 210 leaves. Collation: $\left.A^{6} a-f^{6} g^{4} h-k^{6} l^{4} m-o^{6} p^{4} q-s^{6} t^{4} v-y^{6} z^{4} \&^{6}\right)^{6} A^{6}$ $\mathrm{B}^{4} \mathrm{C}-\mathrm{E}^{6} \mathrm{~F}^{4} \mathrm{G}-\mathrm{I}^{6} \mathrm{~K}^{4} \mathrm{~L}^{6} \mathrm{M}^{4}$. NK 1051, NK 0339, NK 0594, NK 0596, NB 9173.

- Den groten herbarius met al sijn figueren, Antwerp, Claes de Grave 18 June 1526, $2^{\circ}, 188$ leaves. Collation:66 $\left[{ }^{4}\right]$ a-z $\left.{ }^{6 / 4} \&^{4}\right)^{6}$ A-M ${ }^{4 / 6}$. NK 1052, NB 9174.

- Den groten herbarius Met alden figueren der Cruyden, [Utrecht,] Jan van Doesborch 18 January $1532,2^{\circ}, 196$ leaves. Collation: $\left.\%^{4} \mathrm{a}^{4} \mathrm{z}^{4} \&^{4}\right)^{4} \mathrm{~A}-\mathrm{Z}^{4}$. NK 3145 , NB $9171 .^{67}$

- Den groten herbarius met al sijn figueren, Antwerp, Claes de Grave 20 June 1533, $2^{\circ}$, 198 leaves. Collation: $\left.+{ }^{4} \mathrm{a}-\mathrm{z}^{6 / 4} \&^{4}\right)^{6} \mathrm{~A}-\mathrm{M}^{4 / 6} \mathrm{~N}^{4} \mathrm{O}^{6}$. NK 1053, NB $9175 .{ }^{68}$

- Den groten herbarius met alden figueren der cruyden, Utrecht, Jan Berntsz, the last day of August $1538,2^{\circ}, 186$ leaves. Collation: $\%{ }^{4} \mathrm{a}-\mathrm{z}^{4} \&^{4} \mathrm{~A}-\mathrm{V}^{4} \mathrm{X}^{6}$. NK 1054, NB 9192.

- Den groten herbarius met al sïn figueren der Cruyden, Antwerp, Symon Cock $1547,2^{\circ}, 178$ leaves. Collation: A-Z4 $a-v^{4} x^{6}$. NK 0597, NB 2645.

66 The signature of the first quire has not been preserved in any of the three examined copies of the $15^{2} 6$ edition, due to (partial) loss of pages. It must have been identical to that in the 1533 edition - a cross symbol—as the first quire is identical in both editions (except for the first leaf with the title page).

67 Franssen, Tussen tekst en publiek, 36-37, 72, and 199 assumes that Van Doesborch had already published a now-lost edition of Den groten herbarius around 1520; see above, note 23. The USTC lists an edition of $15^{22}$ (https://www.ustc.ac.uk/editions/443649,

accessed March 10, 2020), but this seems to be incorrect: of the two copies mentioned of this edition, the one in Oxford is in fact the 1532 edition, while the one in Ghent is listed by mistake. I thank the staff of the University Library of Ghent for checking this.

68 A reissue of the $15^{26}$ edition, with the exception of the title page and the added treatises at the end; see above, note 15 . 


\section{A.2 Appendix 2: Examined Copies of Den groten herbarius}

Unless otherwise indicated, the number of different annotators per copy and the datings of the annotations are uncertain, but they are in any case (based on handwriting and spelling) sixteenth- or seventeenth-century. ${ }^{69}$

1514-Ao4 ${ }^{70}$ Amsterdam (Nl), University Library, otM: Ned. Inc. 509

Heavily used (paper worn). Missing pages in quires a-g replaced by photocopies (from 1514-Ho4). Rubricated from quire q onwards. Several "+"-symbols, some other small symbols, nota (a few in red by the rubricator), occasional keywords (Dutch).

1514-A12 Antwerpen (Be), Museum Plantin-Moretus, $R 46.7$

Heavily used (paper worn). Traces of pins (one pin still present), especially in quires b and c. Some keywords (remedies; Dutch), especially in index.

1514-Bo2a Bruxelles (Be), Bibliothèque royale/ Koninklijke Bibliotheek, VH 6.192 A (RP)

Underlinings and keywords (remedies, plant names; Dutch, Latin) throughout the book, several in index. Several passages on lust and devil have been marked and/or crossed out. Some coloured woodcuts, only in the first quires (a-c).
Order of the Celestines in Heverlee, with shelfmark from their library: "theca 64"

1514-Bo2b Bruxelles (Be), Bibliothèque royale/ Koninklijke Bibliotheek, VH 6.696 A (RP)

Extensively annotated, mostly in Latin, some in Dutch (multiple sixteenth-century hands). Chapters from Macerfloridus copied in the margins. Many keywords (remedies, plant names; also in index), underlinings, nota, manicules. Qualities of plants (hot/cold, moist/dry) written inside woodcuts. A few woodcuts annotated with comments on a plant's appearance (fols. $\left.\left.i 4^{r},\right) 1^{r}, A 4^{r}\right)$. Last page full of (crossed-out) owners' marks.
${ }^{*}$ Rombout de Vryese. Rombout annotates in clumsy Latin in a distinct hand, probably around 1600 .

* "Loys de Joncheere bailliu ontfancghere van watervliet Ende waterdijck" (bailiff and "receiver" of Watervliet and Waterdijck)

69 Copies I have not been able to examine: Dresden, Sächsische Landesbibliothek-Staatsund Universitätsbibliothek (SLUB) 1.B.2174 (ed. 1547); Göttingen, Niedersächsische Staatsund Universitätsbibliothek 4 MAT MED 34/69 RARA (ed. 1532); Louvain, Katholieke Universiteit, Maurits Sabbebibliotheek G B IB: Godgeleerdheid $\mathrm{P}_{5} 8 / \mathrm{F}^{\circ *} 2$ HERB 1532 (ed. 1532); Munich, Bayerische Staatsbibliothek Res/4 Phyt. 145 (ed. 1532); New York, Pierpont Morgan Library PML 25982 (ed. 1538); Nijmegen, Klooster Collegium Berchmanianum (ed. 1532); Oxford, University Libraries, Sherard 470 (ed. 1532); Paris, Muséum d'Histoire Naturelle (ed. 1533).

70 The ID is composed of the year of publication followed by the code of the holding institution as used in NB. 
(cont.)

Early modern traces of use

Early modern owner(s)

1514-Ho4 Den Haag (Nl), Koninklijke Bibliotheek, KW 227 A 12

Stains, frayed edges. Rubricated. Annotated throughout, but mostly

first pages. Nota, keywords (remedies; Dutch, Latin, multiple sixteenth-century hands). Some brief additions (Dutch). Several pins and traces of pins.

1514-Ko7 København (Dk), Det Kongelige Bibliotek, $4^{\circ}$ Farmakognosi (Cuba)

Lavishly coloured woodcuts, colours not always true to nature.

Additional flowers drawn (doodled) crudely in some woodcuts.

Keywords (remedies, plant names; Dutch; also in index and urine treatise) and some other brief annotations (Dutch), many heavily

faded. Occasional symbols.

1514-LMB Leiden (Nl), Museum Boerhaave, BOERH g 3301

Lavishly coloured woodcuts. Several woodcuts cut out in the first * Willem Barentsoen

quires. Many additional recipes (Dutch), perhaps by Willem Barent- ${ }^{*}$ Lambertus Optio (Opsy), born 1583, soen. Nota, underlinings, annotation quaet or quaetheyt (marking harmful substances). son of Lambert Cornelisz. and grand-nephew of Willem Barentsoen $^{71}$

1514-N53 New York(US), Metropolitan Museum of Art, 44.7.32

Index in first quire missing, pages of final quires $L$ and $M$ very smudgy and frayed. A few keywords (remedies, plant names), cross references to other chapters, added recipes, Dutch and Latin. Some "fransos verhaghen xxxi" (i.e. 1531, or 1631 , or aged 31 ?)

"+"-symbols. Many small marginal stripes in pencil (?), apparently markings. Fol. $\mathrm{v}^{\mathrm{r}}$ criticism on the verisimilitude of the woodcut of Malloete.

1514-Wo2 Washington D.C. (US), Library of Congress, Rosenwald 1128

Planet symbols drawn in some 15 o woodcuts. Severely faded marginalia, largely illegible; at least some of them seem to be recipes and additions on medicinal qualities (Dutch, 16th c.). Underlined headings in index, heavily faded.

1526-Lo1 London (UK), British Library, 546.i.8.

Endpaper full of largely illegible owners' marks, including that of Petrus Saxsi. Annotations often illegible (Dutch, German, Latin, also Danish and English?). Many "+"-symbols, tota and "dat". A few other symbols, keywords, underlinings, "NB" (by Petrus Saxsi ${ }^{72}$ ).
Petrus (Peder) Nicellai Saxsi, dated: 1642.

$71 \quad$ See above, "Marks of Ownership."

72 See above, note 43 . 
(cont.)

Early modern traces of use

1526-N53 New York (US), Metropolitan Museum of Art, 44.7.33

Sixteenth-century parchment binding. One annotator has drawn body parts in the margins to mark recipes related to these body parts, including eyes, ears, teeth, penises, feet, breasts. Also various chalices, and on $\mathrm{p}^{\mathrm{v}}$ a vomiting man. Several pins ( $\left.\mathrm{g}_{3}, \mathrm{~F}_{5}\right)$ and traces of pins. Added recipes in margins. Keywords (remedies, plant names; Dutch), underlinings, nota. Calculations (numbers) on end leaves front and back.
Early modern owner(s)

* Three owners marks of Magdalena van Tuerenhout, twice of which written as a child in a neat and inexperienced hand ("maddalencken uan turenhooudt", "maddelencken uan tuerenhouijt”), once in adult hand dated "xi Julij Anno $1585^{\prime \prime 73}$

* "A. De Neeue"/“In vsum Adriani nepotis"74

* Hermannus Alexandrij

* Jasper van Tuernout "brower In den enghel In die balderrije Tot liere"

1526-Uo1 Utrecht (Nl), Universiteitsbibliotheek, Rariora qu 133

Practically no traces of use. A few pages missing, including first quire and final page.

1532-A17o Antwerpen (Be), Erfgoedbibliotheek Hendrik Conscience, $\mathrm{G}_{142285}\left[\mathrm{C}_{2-}-519 \mathrm{f}\right]$

All woodcuts lavishly coloured, including decorative borders, initials, and scholars' bust figures. Especially first and last quires heavily worn. Occasional annotations: added recipes (Latin; largely cut off), underlinings, crossed out text passage, keywords in index (Dutch).

73 Furthermore, the inscription "leene" appears in several places in the margins, e.g. fol. $\mathrm{p}^{\mathrm{v}}$. The date (1585) is incorrectly listed as 1565 in the online catalogue of the Metropolitan Museum (http://www.metmuseum.org/art/collection/search/343849, accessed February 9, 2020).

74 This Adriaen de Neeve was perhaps related to Magdalena van Tuerenhout. His name is below hers on the front endleaf, written in the same hand. 
(cont.)

Early modern traces of use

Early modern owner(s)

1532-B16 Bethesda, MD (US), National Library of Medicine, HMD collection, WZ 240 I38Du 1536

Bound with Johannes Indagine, Chyromantia (Utrecht: Jan Berntsz, 1536) (text 1) and Hieronymus Brunschwig, Dits dat hantwerck der cirurgien (Utrecht: Jan Berntsz, 1535) (text 3). All three have been hand-coloured, rubricated and annotated by the same person: the red and blue rubrication inks are also used in the woodcuts and in the annotations (e.g. dual-colour manicules, nota in red, rubricated annotations). Herbarius has by far the most annotations of the three. Many keywords (remedies, plant names; Dutch, Latin; also in index), several additional recipes (Dutch) in margins. A quote from Ecclesiasticus 38:9-15 on ar ${ }^{\mathrm{r}}$. Many traces of pins. "pro domino reijnero in Harlingen." The sixteenth-century inscription suggests that the book was a gift and that Reijnerus was a cleric.

\section{2-Wo2 Washington D.C. (US), Library of Congress, Rosenwald 1107}

Many underlinings, keywords (remedies; Dutch), vertical wavy lines, manicules and symbols in the margins throughout. At least two annotators; some passages have been underlined twice. All paragraphs on remedies marked by a letter as a structuring aid (starting anew per page rather than per chapter). Passages on qualities of plants marked with "q", recipes with "R". Register of cures numbered by hand.

1533-B16 Bethesda, MD (USA), National Library of Medicine, HMD collection, WZ 240 H823Du 1533 and Bathtub coll. box 5 no. 6

All chapters numbered by hand in large Arabic numerals. In the same hand: a few keywords (especially plant names; Latin, Dutch). A few additional recipes in one or two other (smaller, neater) hands (Dutch). Bound with added leaves (front: 4 leaves, back: 10) with 16th/17th-c. handwritten notes (Dutch), mainly medical recipes and a list of injuries equated to sums of money and pilgrimage routes (apparently as a kind of amends in a legal context). 19 further leaves from an earlier binding are preserved in a separate folder ("Bathtub collection"), including several letters from the 1640 f from a Willem Uijst of Maastricht. 16th-c. owner's mark cut out and pasted on front endleaf: Wilhelmus vander smissen. 
(cont.)

Early modern traces of use

1533-N53 New York (US), Metropolitan Museum of Art, 44.7.34

Many small stripes, $\mathrm{x}$-es, braces, underlinings and an occasional nota, mostly in pencil (?) and occasionally in red crayon. Many small "+"-symbols with serifs in red crayon. A few added recipes (Dutch). Several added and corrected entries in the alphabetical index at the beginning. In the index from head to feet: keywords (Latin, Dutch), underlinings (mostly in red crayon).

Early modern owner(s)

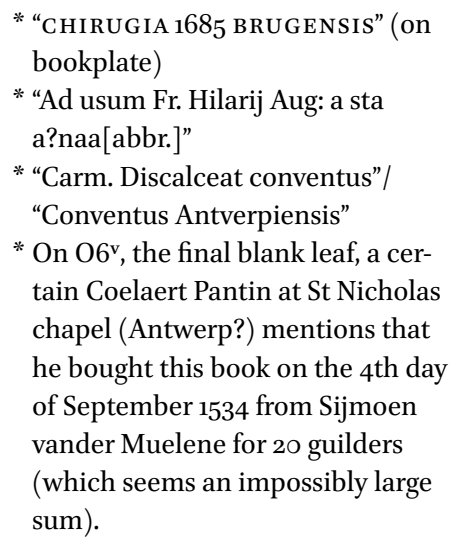

1538-Cor Cambridge (UK), University Library, Syn.4.53.6

Old parchment binding. Many underlinings and keywords (reme-

Niclaes vanden steene. Dated: 1597 . dies mostly in Dutch, plant names and qualities mostly in English). Niclaes also notes the book price: "L Pages trimmed, parts of annotations lost. Title page and first part of $\quad \beta$ vlems" (5o Flemish shillings?) ${ }^{75}$ index missing. Instead, a blank leaf with additions to the index in English. At the end, remains of a blank leaf covered in drawings of hands and a naked female figure, in black crayon and ink (second half 16th century?), another blank leaf with a list of English units of capacity.

1538-Ho4 Den Haag (Nl), Koninklijke Bibliotheek, KW 226 A 8

Many nota, some underlinings and keywords (plant names; Latin, Dutch). Pages trimmed, parts of annotations lost. E1 ${ }^{\mathrm{v}}$ annotation Sij vis sanis esse nolijte fructijbus esse, $\mathrm{H}_{4}{ }^{\mathrm{r}}$ sanis esse nolite fructibus.

1538-Lo1 London (UK), British Library, 448.f.3.

No annotations apart from owner's mark (lost because of trimmed pages?). One coloured woodcut at the beginning, two at the end.

"Dignen van Hueculum Jan gheerts dochtere."76

75 Compared to prices mentioned in the database Early Modern Book Prices (http://emobook trade.unimi.it/db/public/prices, accessed February 9, 2020) this seems unlikely expensive.

${ }_{7} 6$ See above, "Marks of Ownership." 
(cont.)

1547-A17o Antwerpen (Be), Erfgoedbibliotheek Hendrik Conscience, G ${ }_{11965}\left[\mathrm{C}_{2-569} \mathrm{f}\right]$

Many curly symbols and crudely drawn manicules. Keywords

"Neelken van [..?]uffelsen"77

(remedies, plant names; Dutch), a few notes on medicinal work-

ings. Multiple additions, corrections and "+"-symbols in index.

Pages trimmed, parts of annotations lost. Three woodcuts crudely

and partially coloured.

1547-A12 Antwerpen (Be), Museum Plantin-Moretus, $R 44.7$

Clean copy. A few "+"-symbols, especially in index, occasionally other symbols. $\mathrm{R}_{4}{ }^{\mathrm{v}}, \mathrm{Si}^{\mathrm{r}}, \mathrm{Si}^{\mathrm{v}}$ : cross-references to earlier/later pages in Above colophon: "Orate pro Confesthe book (different hand than Henricus de Beringhen's inscription), frater henrico de beringhen." 78 unclear what is referred to.

\section{7-Go3 Gent (Be), Centrale Bibliotheek van de Universiteit Gent, Bib. Acc 3404}

Old parchment binding. Around 125 woodcuts coloured, limited palette. Blank leaf with handwritten supplement to index at the end, dated 2 November 156o. Additions and corrections in index. A few nota, small stripes, keywords (remedies; Dutch). Additional recipe (Dutch) on final endleaf.

\section{7-Lo1 London (UK), British Library, 449.i.19.}

First quire lacking. Many stains and smudges, especially in first and last quires. Keywords (remedies; Latin, Dutch), mostly in second half of the volume. Final blank page filled with additional recipes in Dutch.

1547-L39 London (UK), Wellcome Library, 3317/D

Few traces of use. A few underlinings in faded brown-orange ink, $2 \times$ the word "DEOLORIS", a "+"-symbol. One woodcut partially coloured.

77 The name is written upside down in the margin of fol. $\mathrm{B}_{4}^{\mathrm{r}}$, possibly as a pen trial. One or two letters before " $u$ " may be missing. Because of the peculiar positioning, it is not certain whether Neelken was indeed the owner of the volume, or maybe a beloved one whose name the annotator used to test the pen.

78 See above, "Marks of Ownership." 
(cont.)

Early modern traces of use

Early modern owner(s)

1547-N53 New York (US), Metropolitan Museum of Art, 44.7.35

First and last quires smudgy and frayed. Many added entries in the

"Den eersaemen Joannes Ackermans" index, while the rest of the volume contains few annotations and (or Schiermans?) the pages are clean. Drawings: a man with hat and sword $\left(\mathrm{F}_{3} \mathrm{r}\right)$, a cross with a sign "INRI" on top $\left(\mathrm{n} \mathrm{r}^{\mathrm{r}}\right)$. A few keywords (remedies; Dutch) and underlinings. One added recipe in the margin (Dutch). Eight added leaves with handwritten recipes at the end, one of them noting the year 1598 . Some of these pages blank, apparently intended for later additions. Folio numbers added on all leaves, continuing on the added leaves. The index from head to feet also has page (!) numbers by an earlier hand.

1547-Uor Utrecht (Nl), Universiteitsbibliotheek, Rariora qu 294

Few traces of use. First quire lacking, many frayed edges. Tiny "o" in brown ink written inside the borders of some 30 woodcuts (esp. in quires B-Q). 